\title{
COMPACTION OF COHESIONLESS MATERIALS
}

\author{
by \\ J. R. Compton \\ W. E. Strohm, Jr.
}

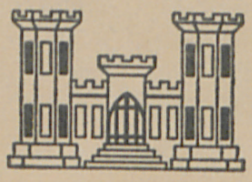

August 1968

\author{
Sponsored by \\ Office, Chief of Engineers \\ U. S. Army
}

Conducted by

U. S. Army Engineer Waterways Experiment Station CORPS OF ENGINEERS

Vicksburg, Mississippi

Each $t$

prior a

Approved for Public Release; Distribution Unlimited

must have 


\title{
COMPACTION OF COHESIONLESS MATERIALS
}

\author{
by \\ J. R. Compton \\ W. E. Strohm, Jr.
}

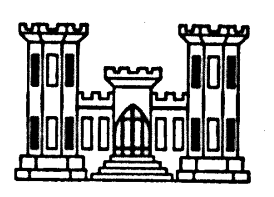

August 1968

\author{
Sponsored by \\ Office, Chief of Engineers \\ U. S. Army
}

Conducted by

U. S. Army Engineer Waterways Experiment Station CORPS OF ENGINEERS

Vicksburg, Mississippi

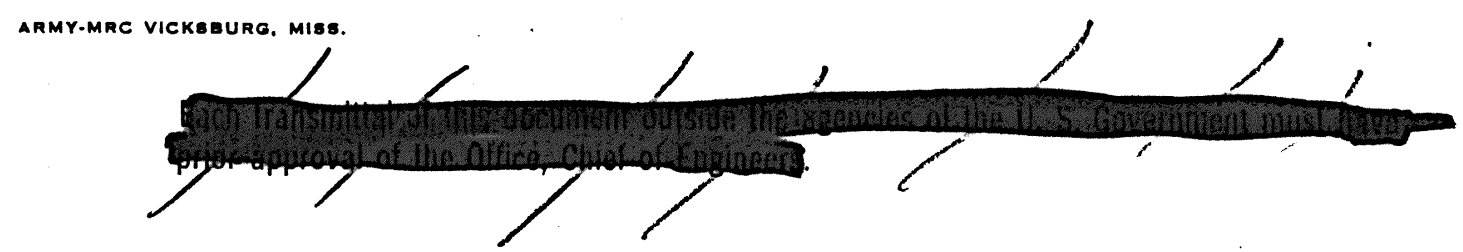




\section{FOREWORD}

The investigation reported herein was authorized by letter from the Office, Chief of Engineers (ENGWE), dated 2 March 1959, subject: Proposed Civil Works Investigation Program - FY 1960.

The investigation was initiated during FY 1960. During the period FY 1959-FY 1961, a survey was made of Corps division laboratories to obtain information concerning current compaction procedures for cohesionless soils. Laboratory compaction tests were performed in the U. S. Army Engineer Waterways Experiment Station (WES) laboratory on two soils (a poorly graded sand (SP), and a sandy gravel (GW)) during the period FY 1960FY 1964. Interim reports of the test results were prepared in FY 1963 and FY 1964. Additional laboratory compaction tests were performed on a third soil, a well-graded sand (SW), in FY 1965.

This investigation was conducted under the general direction of Messrs. W. J. Turnbull, W. G. Shockley, A. A. Maxwell, J. R. Compton, and R. W. Cunny.

Principal engineers conducting the investigation and analyzing results were Messrs. R. C. Sloan and W. E. Strohm, Jr. This report was prepared by Messrs. Compton and Strohm.

Directors of the WES during the preparation and publication of this report were COL Edmund H. Lang, CE; COL Alex G. Sutton, Jr., CE; COL John R. Oswalt, Jr., CE; and COL Levi A. Brown, CE. Technical Director was Mr. J. B. Tiffany. 
Purpose and Scope . . . . . . . . . . . . . Background

PART II: WES IABORATORY INVESTIGATION . . . . . . . . . 3

Materials Tested ..................

Test Apparatus and Procedures . . . . . . . . . .

Test Results ....................

PART III: COMPARISON OF FIEID AND IABORATORY COMPACTION DATA. • •

Survey of CE Offices. . . . . . . . . . . . .

Comparison of Laboratory Test Results with Field Data

on Materials Tested at WES.

PART IV: CONCLUSIONS AND RECOMMENDATIONS. . . . . . . . . TABLES $1-13$ 
CONVERSION FACTORS, BRITISH TO METRIC UNITS OF MEASUREMENT

British units of measurement used in this report can be converted to metric units as follows:

$\frac{\text { Multiply }}{\text { inches }}$
cubic feet
cubic yards
pounds
pounds per square inch
pounds per cubic foot
tons
foot-pounds
gallons
miles per hour

\begin{tabular}{l}
\multicolumn{1}{c}{ By } \\
\hline 2.54 \\
0.0283168 \\
0.764555 \\
0.45359237 \\
0.070307 \\
16.0185 \\
907.185 \\
0.138255 \\
3.78533 \\
1.609344
\end{tabular}

To Obtain

centimeters

cubic meters

cubic meters

kilograms

kilograms per square centimeter

kilograms per cubic meter

kilograms

meter-kilograms

liters

kilometers per hour 


\section{SUMMARY}

This report contains data on laboratory and field compaction of cohesionless soils obtained from a survey of Corps of Engineers division laboratories, and results of different types of laboratory compaction tests performed in the U. S. Army Engineer Waterways Experiment Station (WES) laboratory on three cohesionless materials.

The tests at WES were conducted to study various laboratory compaction test methods used for cohesionless materials. The three materials tested were a poorly graded sand (SP), a well-graded sand (SW), and a sandy gravel (GW). Impact, Providence vibrated density, vibratory table, and gyratory compaction test methods were used.

Replicate tests were conducted on each soil to determine the variations in maximum dry density resulting from different test methods. Different technicians conducted the replicate tests in order that the variations in test results due to different techniques could be determined. Selected tests were also conducted on dry and wet specimens to determine the effect of water content on resulting densities. Gyratory tests were conducted using different angles of gyration and different vertical pressures to determine the effects of these variables.

Based on the results of the compaction tests on the three materials used in the study it is concluded that the vibratory table test method gives the best reproducibility of results and the modified Providence vibrated density test method gives results comparatively close to those derived from the vibratory table test method. 


\section{PART I: INTRODUCTION}

1. Cohesionless materials are used by the Corps of Engineers ( $\mathrm{CE}$ ) in many of its projects involving earth fill. Compaction requirements for these materials are established by different types of laboratory compaction tests in the various $\mathrm{CE}$ laboratories. The use of different test methods has not proved to be satisfactory, particularly since compaction in the field often produces densities differing considerably from those specified on the basis of laboratory tests. A standard laboratory test for cohesionless materials is needed that will provide a realistic basis for specifying density values to be obtained in the field.

\section{Purpose and Scope.}

2. The purpose of the investigation reported herein was to study various laboratory compaction test methods used for cohesionless materials and to compare selected laboratory and field densities.

3. This investigation was conducted in two parts. One part involved performance of various compaction tests on three different cohesionless soils. The compaction test methods studied were (a) the standard effort impact method (STD); * (b) the Providence vibrated standard method (PVD); (c) a modified Providence vibrated method (MPVD); (d) two vibratory table methods (VT) and (MVT); and (e) the gyratory compaction method (GC). The materials used were a poorly graded sand (SP) from the Hopkinton-Everett Project, New Hampshire; a well-graded sand (SW) from West Thompson Dam, Connecticut; and a sandy gravel (GW) from Painted Rock Dam, Arizona. The other part of the study consisted of a survey of laboratory compaction test equipment and test procedures used in CE laboratories for cohesionless materials and comparisons of available field density test data with corresponding laboratory compaction test data, both from the WES tests

* Symbols following test method names were assigned arbitrarily for convenience and will be generally used hereinafter to identify the various test methods. 
and from test data supplied by the CE Districts.

4. In this report, the density results of the various laboratory compaction tests are compared with one another and with results of field density tests on similar materials compacted in the field.

\section{Background}

5. The investigation reported herein was initiated in FY 1960. During FY 1960 and FY 1961, field and laboratory compaction data from CE divisions were analyzed, and laboratory compaction tests were performed at WES using the Hopkinton-Everett sand (SP) and Painted Rock sandy gravel (GW). Laboratory compaction test methods used during these periods were the STD, the PVD and a modification thereof, and the VT method. An unpublished report of the results of the tests performed in FY 1960 and FY 1961 was prepared in FY 1962. In FY 1963, GC tests were performed on the sand (SP) and sandy gravel (GW), and an unpublished report of the results of these tests was prepared in FY 1964. In FY 1965, laboratory compaction tests were performed on a third material, a wellgraded sand (SW) from West Thompson Dam, having a gradation intermediate between that of the sand (SP) and sandy gravel (GW).' The compaction test methods used on this material were the MPVD, the MVT, and the GC methods.* MVT tests and additional GC tests were also performed on the sand (SP) and the sandy gravel (GW) to provide more complete data.

* Procedures for the MPVD and MVT methods are now outlined in "Appendix XII: Relative Density" in "Laboratory Soils Testing," EM 1110-2-1906, 10 May 1965, Headquarters, Department of the Army, Washington, D. C. 


\section{Materials Tested}

6. Three cohesionless materials were used in the WES laboratory investigation. One was a uniform, medium to fine sand (SP) furnished by the New England Division from borrow area D, Hopkinton-Everett Dam, Hopkinton, New Hampshire. The borrow area was in a glacial outwash deposit. The second material was a sandy gravel (GW) furnished by the Los Angeles District from the pervious borrow area of Painted Rock Dam, Gila Bend, Arizona. The borrow area was in the streambed of the Gila River, and the larger particles taken from the area were rounded to subrounded in shape. The third material was a well-graded sand (SW) furnished by the New England Division from a pervious borrow area (borrow area C) of West Thompson Dam, Thompson, Connecticut. The borrow area was in an alluvial terrace deposit along the Quinebaug River. The sand (SW) was selected to provide a gradation intermediate between the gradations of the other two materials. The gradation curves for the three soils are shown by numbered lines in fig. 1.

Hopkinton-Everett sand (SP)

7. The sand from the Hopkinton-Everett Project had a maximum particle size of about $3 / 8$ in., * with less than 1 percent of plus No. 4 material. Because of the small amount of plus No. 4 material and the necessity for all compaction specimens of this sand to have the same gradation, the sand was screened on a No. 4 sieve, and the minus No. 4 material was used in the laboratory tests. The gradation of the minus No. 4 material was as follows:

\begin{tabular}{c} 
Sieve No. \\
\hline 4 \\
10 \\
40 \\
200
\end{tabular}

\begin{tabular}{c} 
Percent Passing- \\
\hline 100.0 \\
$97: 6$ \\
72.6 \\
3.4
\end{tabular}

* A table of factors for converting British units of measurement to metric units is presented on page vii. 


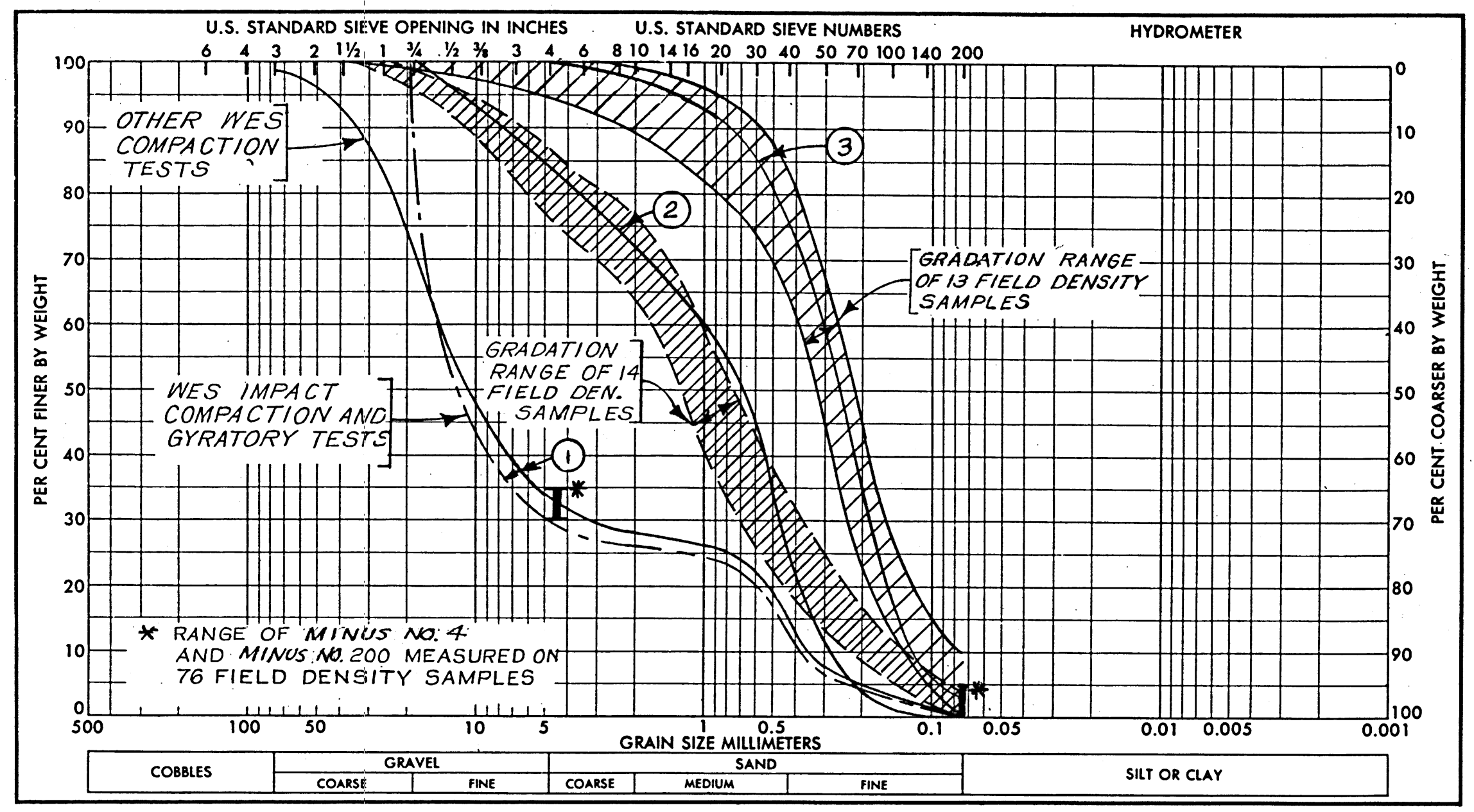

(1) PAINTED ROCK SANDY GRAVEL (GW)

(2) WEST THOMPSON SAND (SW)

(3) HOPKINTON-EVERETT SAND (SP)

Fig: 1. Gradation curves of materials used in WES compaction tests 
Painted Rock sandy gravel (GW)

8. The sandy gravel frcm Painted Rock Dam had a maximum particle size of about 4 in., with about 68 percent of plus No. 4 material. In order to produce compaction specimens of as nearly identical gradation as possible, the sandy gravel was sieved into the following fractions:

$\begin{array}{ll}\text { Passing } & \text { Retained on } \\ 2-1 / 2 \text { in. } & 1-1 / 2 \text { in. } \\ 1-1 / 2 \text { in. } & 1 \text { in. } \\ 1 \text { in. } & 3 / 4 \text { in. } \\ 3 / 4 \text { in. } & 1 / 2 \text { in. } \\ 1 / 2 \text { in. } & 3 / 8 \text { in. } \\ 3 / 8 \text { in. } & 1 / 4 \text { in. } \\ 1 / 4 \text { in. } & \text { No. } 3 \\ \text { No. } 3 & \text { No. } 4 \\ \text { No. } 4 & --\end{array}$

The separate fractions were then recombined in proper proportions as samples were needed for the compaction tests. Impact and gyratory compaction tests were performed on samples of the sandy gravel having a maximum particle size of $3 / 4$ in. with replacement of the plus $3 / 4-i n$. material by an equal amount of material passing the 3/4-in. sieve and retained on the No. 4 sieve (see broken gradation curve 1 in fig. 1); other compaction tests ( PVD and VT) were performed on samples having a maximum particle size of $2-1 / 2$ in. (see solid-line gradation curve $I$ in fig. 1). Where materials have more than 10 percent of plus $2-1 / 2-i n$. material, the customary procedure in the PVD test is to replace the plus 2-I/2-in. material with an equal weight of material passing the 2-1/2-in. sieve and retained on the 1-in. sieve. Since the sandy gravel tested had only a few percent of plus 2-I/2-in. material, the PVD tests were performed on the minus 2-1/2-in. fraction without replacement. This material was also used in the VT tests. West Thompson sand (SW)

9. The sand (SW) from West Thompson Dam had a maximum particle size of $3 / 4$ in. and 15 percent of plus No. 4 material. The sand was received in bags, and gradation tests on representative specimens from each of six bags selected at random indicated a maximum variation in gradation 
of only about 5 percent; it was therefore concluded that the sand in all bags was essentially of the same gradation. To ensure that material for each compaction specimen had as nearly identical gradation as possible, the specimens were prepared by recombining the following fractions in the percentages shown below:

\begin{tabular}{lcc} 
Passing & Retained on & Percent \\
\cline { 2 - 3 } $3 / 4$ in. & No. 4 & 15 \\
No. 4 & No. 10 & 13 \\
No. 10 & No. 20 & 16 \\
No. 20 & No. 40 & 32 \\
No. 40 & No. 200 & 24 \\
No. 200 & -- & 0 \\
& Total & 100
\end{tabular}

Test Apparatus and Procedures

10. Data on the compaction apparatus and procedures used are summarized in table 1. Fig. 2 shows some of the compaction test apparatus used in the tests. A schematic diagram of the Providence apparatus is shown in fig. 3. The apparatus for the modified Providence and modified vibratory table methods are illustrated in Appendix XII, "Relative Density," EM 1110-2-1906,* but are not shown in this report. The gyratory compaction apparatus is shown in figs. 4 and 5. The procedures used in conducting the tests are briefly described in the following paragraphs. STD tests

11. SID tests were performed on the sand (SP) and the sandy gravel (GW) as shown in table 1. Molds of both 4- and 6-in. inside diameter were used in compacting the sand to check possible effects of mold size on density and optimum water content. The 5.5-1b rammer was used as the standard rammer for compaction tests on the sand (SP) and sandy gravel (GW); supplemental tests using a 10-1b rammer were performed on the sandy gravel. Essentially the same compaction effort was used in all impact tests; the effort was equivalent to that of the STD test $(12,400 \mathrm{ft}-1 \mathrm{~b}$

* Headquarters, Department of the Army, "Laboratory Soils Testing," EM 1110-2-1906, 10 May 1965, Washington, D. C. 

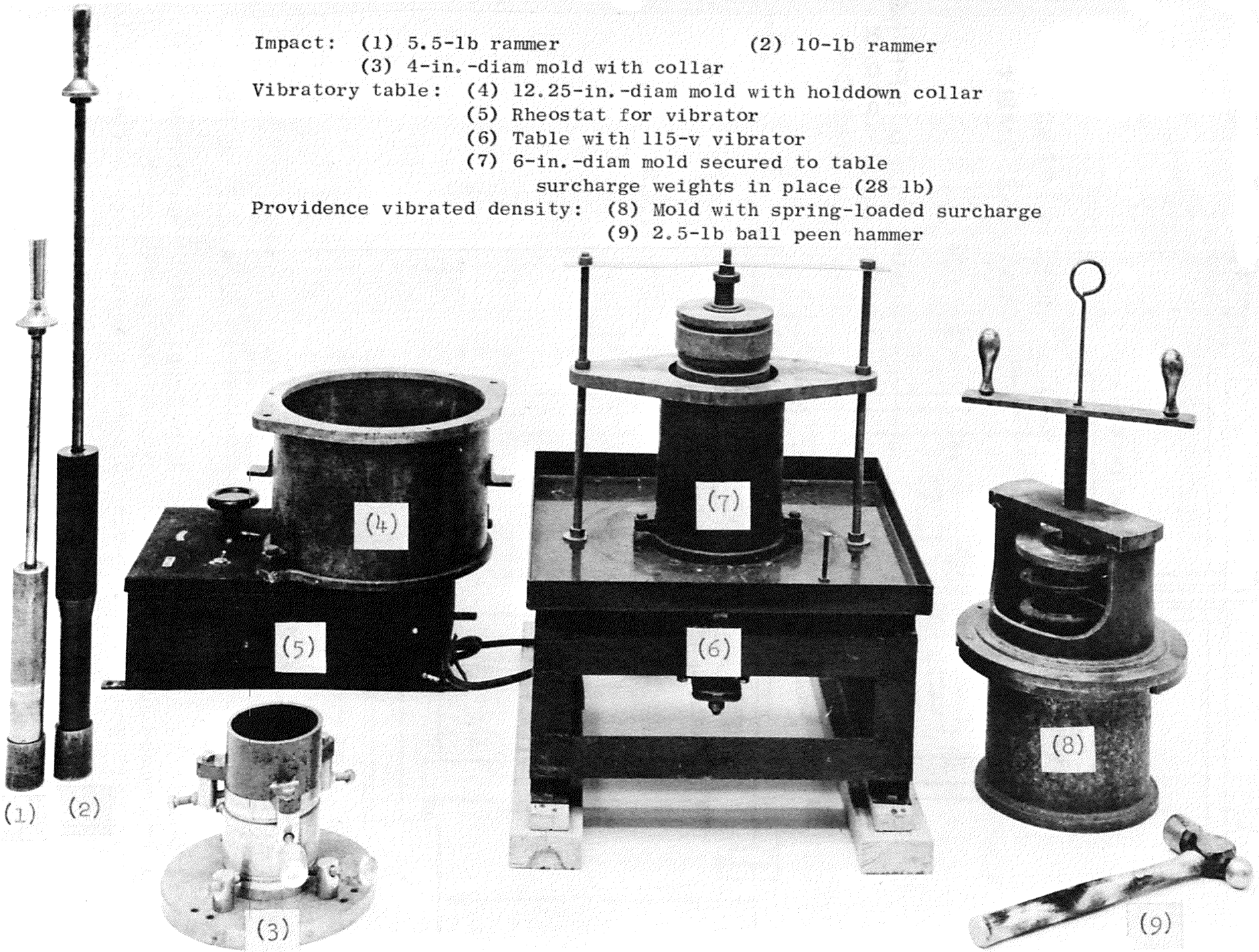

Fig. 2. Impact, vibratory table, and Providence vibrated density compaction apparatus used in WES tests 


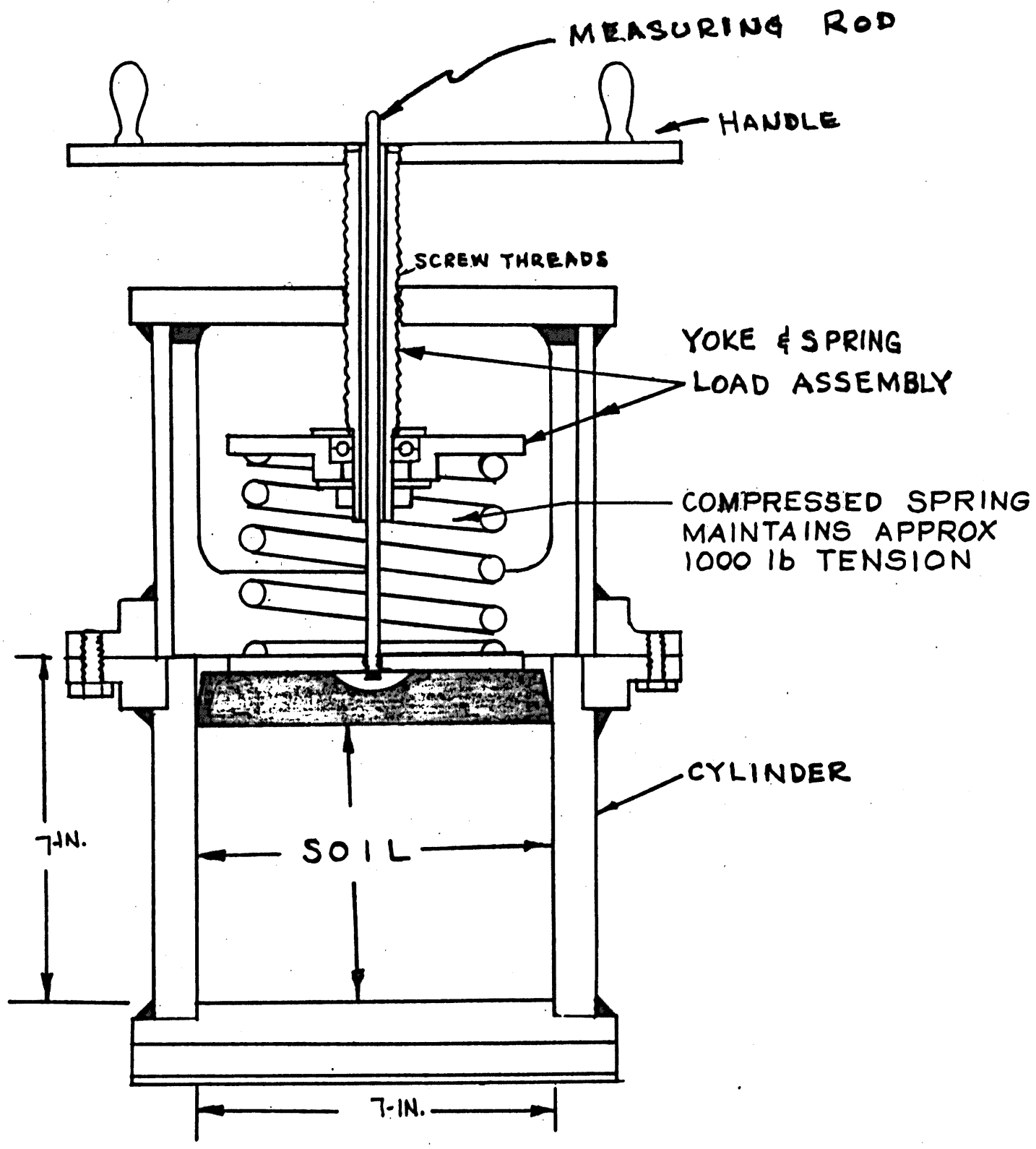

NOTES :

Spring is compressed to maintain approximately 1000-1b pressure on soll specimen.

In modified test, spring is replaced by 1-psi static surcharge. Test is conducted by forcefully hitting sides of mold with

2-1/2-1b ball peen hammer unt1l no further measurable settlement occurs.

Fig. 3. Sketch of Providence vibrated density apparatus 


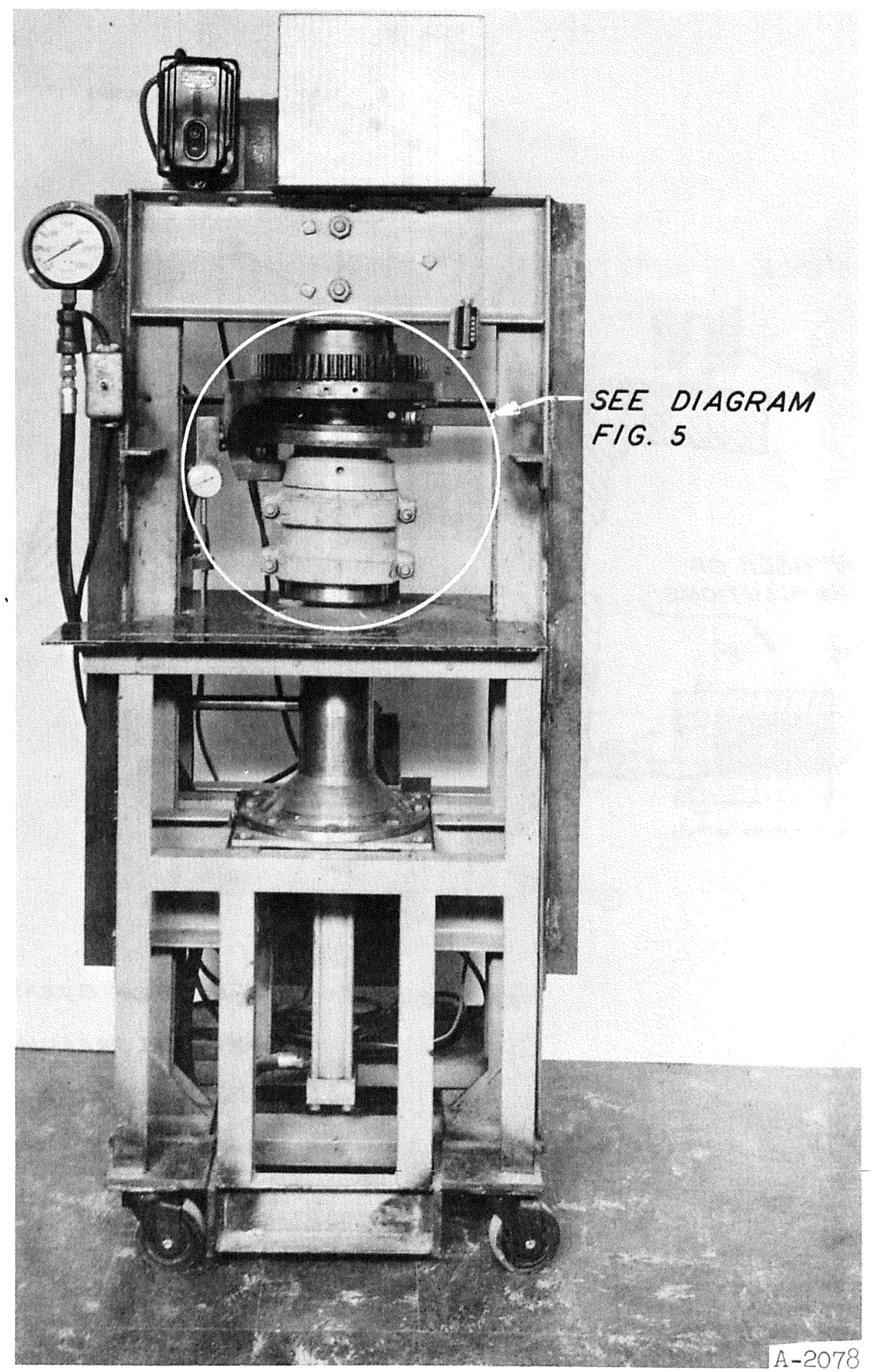

Fig. 4. Gyratory compactor 


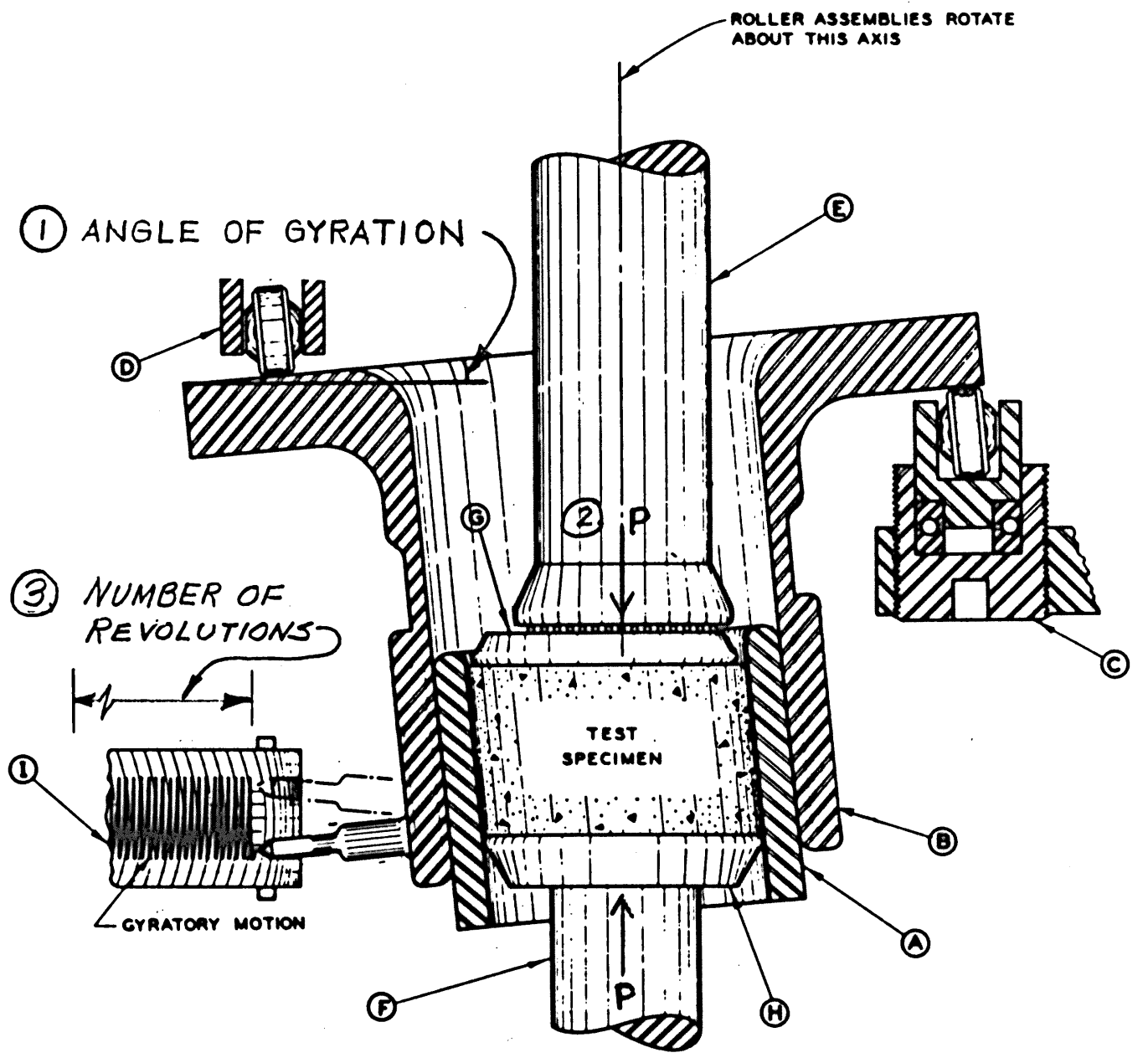

VARIA bLES: (1) ANGLE of GyRATION

(2) VERTICAL PRESSURE, $P$

(3) NUMBER OF REVOLUTIONS

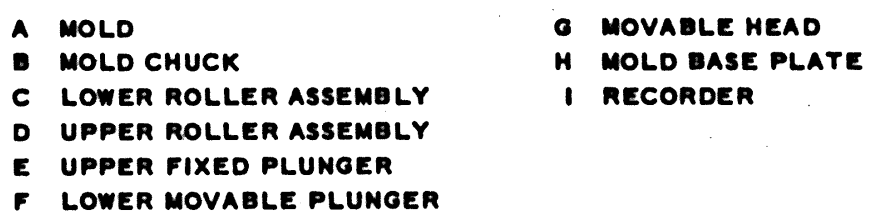

Fig. 5. Diagram illustrating basic elements of gyratory compactor 
per cu ft). The impact tests were performed on samples at various water contents to determine the maximum density at optimum water content. Tests were also performed on ovendry material.

PVD tests

12. The PVD test is performed on materials having maximum particle sizes up to 2-1/2 in. The PVD apparatus (fig. 3) consists of a heavy steel cylinder with a yoke and spring assembly. About 12 lb of ovendry soil is placed in the mold at one time, and a 1000-1b, spring-loaded surcharge is applied by turning the handle as far as possible by hand to keep the spring at full deflection.* The side of the mold is then struck forcefully with a 2-1/2-1b ball peen hammer at the rate of about 40 blows per minute. The blows are spaced evenly around the mold over the area adjacent to the soil. Striking is continued, keeping the spring in compression until no additional settlement of the measuring rod is observed. The height of the compacted sample is then measured, and the dry density is computed.

MPVD test

13. In the MPVD test, which was performed on ovendry samples of the sands and sandy gravel, the PVD equipment and procedure described in paragraph 12 were used except that a 38.5-1b static surcharge, providing a pressure equivalent to $1.0 \mathrm{psi}$, was substituted for the springloaded surcharge. This modified test is the one now outlined in Appen$\operatorname{dix}$ XII, EM 1110-2-1906.**

VT tests

14. The apparatus used in the VT tests consisted of a 20- by 20-in. platform mounted with rubber cushions to a steel-frame stand. A rheostatcontrolled vibrating element operating on 110 volts was secured to the bottom of the platform at the center; it vibrated vertically- at 3600 vibrations/min. The rheostat controlled the power delivered to the vibrating element, allowing control of the amplitude. The recommended capacity of the machine was $300 \mathrm{Ib}$. The amplitude of vibration with

* The possibility exists that when the spring is compressed by hand cranking, the applied load may be greater or less than $10001 \mathrm{~b}$.

* Headquarters, Department of the Army, op. cit., p 6. 
the rheostat set at maximum power was measured with an electrical potentiometer and recorder with various lead weights and with the 12.25or 6-in.-diam molds filled with soil and fastened rigidly to the platform. The total weight of the 12.25-in.-diam mold filled with sandy gravel (GW) and spring loaded was about $158 \mathrm{lb}$, and maximum amplitude obtainable was 0.003 in. The total weight of the 6-in.-diam mold filled with sand (SP) and loaded with a 28-1b surcharge was about $66 \mathrm{Ib}$, and the maximum amplitude obtainable was 0.013 in.; with no weight on the vibrating table, the maximum amplitude was $0.043 \mathrm{in.}$

15. Ovendry samples of the sand (SP) were compacted by vibration in the 6-in.-diam by 7-in.-deep mold secured to the platform by a collar and bolts. A hand scoop was used to place the soil in the molds in a single operation. A static surcharge of $1.0 \mathrm{psi}$ was applied prior to vibration. Ovendry samples of the sandy gravel (GW) were compacted by vibration in the 12.25-in.-diam by 12-in.-deep mold, which was secured to the vibrating platform like the smaller mold. A surcharge spring load of $1.0 \mathrm{psi}$ was applied to the top of the soil prior to vibration. The vibration time for both materials was varied from 8 to $20 \mathrm{~min}$; no significant additional settlement was noted after 8 min of vibration. MVT tests

16. The MVT apparatus is similar to that described above, except that the vibratory table and vibrator are heavier, and greater amplitudes are produced. The frequency of this electromagnetic vibrator type apparatus is 3600 vibrations/min, and for the ll-in.-diam mold filled with soil and loaded with the static surcharge, the amplitude was approximately 0.02 in. A source of two-phase, 230-volt alternating current is required for the vibrator. Maximum density tests on the ovendry sands were performed using a $0.1-\mathrm{cu}-\mathrm{ft}$ mold ( 6 in. diam), and tests on the sandy gravel (2-I/2-in. maximum particle size) were performed using a 0.5-cu-ft mold (11 in. diam). The test procedures used were those now outlined in Appendix XII, EM 1110-2-1906.*

* Ibid. 
17. The gyratory compactor used in this investigation was the first one designed and constructed at WES modified to accommodate a 6-in.-diam specimen. The gyratory compactor is shown in fig. 4. Later models incorporate refinements found lacking in this pilot model, but the compaction principle has remained unchanged.

18. Fig. 5 illustrates the principal features of the gyratory compactor. A 6-in.-diam mold containing a known weight of ovendry material to be compacted is clamped in position in the mold chuck, and a gyratory motion is generated by rotation of the roller assemblies on the upper flange of the chuck. The number of revolutions can be varied as desired.** Elevation of the roller assemblies can also be varied, thereby varying the angle at which the gyratory motion is applied. A vertical pressure is applied to the soil specimen throughout the test by a hydraulic ram acting on the specimen base plate. The surfaces of the movable head and base plate stay parallel to each other and perpendicular to the axis about which the rollers rotate. The movable head bears against rollers that allow the plate to move horizontally and the top of the mold to move in a circular motion.

19. The change in height of the specimen is measured throughout the test by a dial gage attached to the column in contact with the specimen base plate in such a manner that the vertical movement of the base plate is measured with reference to the rigid frame of the machine. The dial gage used was one with 2-in. travel. Prior to the actual tests, a steel cylindrical block exactly $4.5 \mathrm{in}$. high is placed between the movable head and mold base plate within the mold. After pressure has been applied to the mold base plate to ensure firm contact of the plates with the steel cylinder, the dial gage is read. The change in gage reading is then subtracted from 4.5 to give the height of the specimen after compaction. With the height, weight, and cross-sectional area of the specimen known, the unit weight of the compacted specimen can then be computed.

\footnotetext{
* J. I. McRae, "Feasibility Study of the Gyratory Machine for Testing Soils," Miscellaneous Paper No. 3-474, Feb 1962, U. S. Army Engineer Waterways Experiment Station, CE, Vicksburg, Miss.

* The GC tests reported herein were carried out to the point at which the last 100 revolutions caused less than l-pcf increase in density.
} 
Hopkinton-Everett sand (SP)

20. Tests other than GC. The results of all tests performed on the Hopkinton-Everett sand (SP) except the GC tests are shown in table 2. Density values are further summarized in table 4 . It can be seen in table 4 that higher densities (by 3.8 pcf on the average) were achieved in the STD tests when the material was compacted dry than when it was compacted at optimum water content. Compaction curves for the STD tests are shown in fig. 6. These curves indicate very close agreement in densities obtained in the STD tests conducted by different operators when the sand was compacted at optimum water content. Gradation tests performed after impact compaction with the 5.5-1b rammer showed less than 1 percent increase in the amount of material passing any one sieve, indicating that particle degradation was probably minor (see fig. 7).

21. The MPVD method produced an average density about 4 pcf higher than that obtained with the original PVD method. Also, density variations between different technicians were slightly greater with the MPVD method than with the PVD method ( 1.6 versus 1.2 pcf). Similarly, the average density obtained using the MVT method was 2.8 pcf higher than that obtained using the VT method (paragraph 14), with slightly more variation in density values obtained by the various technicians than when using the VT method.

22. GC tests. Twenty-two GC tests were conducted on the sand (SP) prepared at three different initial water contents: (a) essentially ovendry, (b) about 7 percent, and (c) about 15 percent (free water was noted in every test on these specimens). Vertical pressures of 30,60 , and $100 \mathrm{psi}$ and angles of gyration of $1 / 2,1$, and 2 deg were used. Those densities of the specimens at which the next 100 revolutions produced only about 1-pcf increase were used for comparing results of the various tests. Plots of density versus number of revolutions for all tests except those with $1 / 2$-deg angle of gyration are shown in fig. 8 . The test conditions and density results are summarized in table 3.

23. Comparison of results of five sets of mechanical analysis tests 

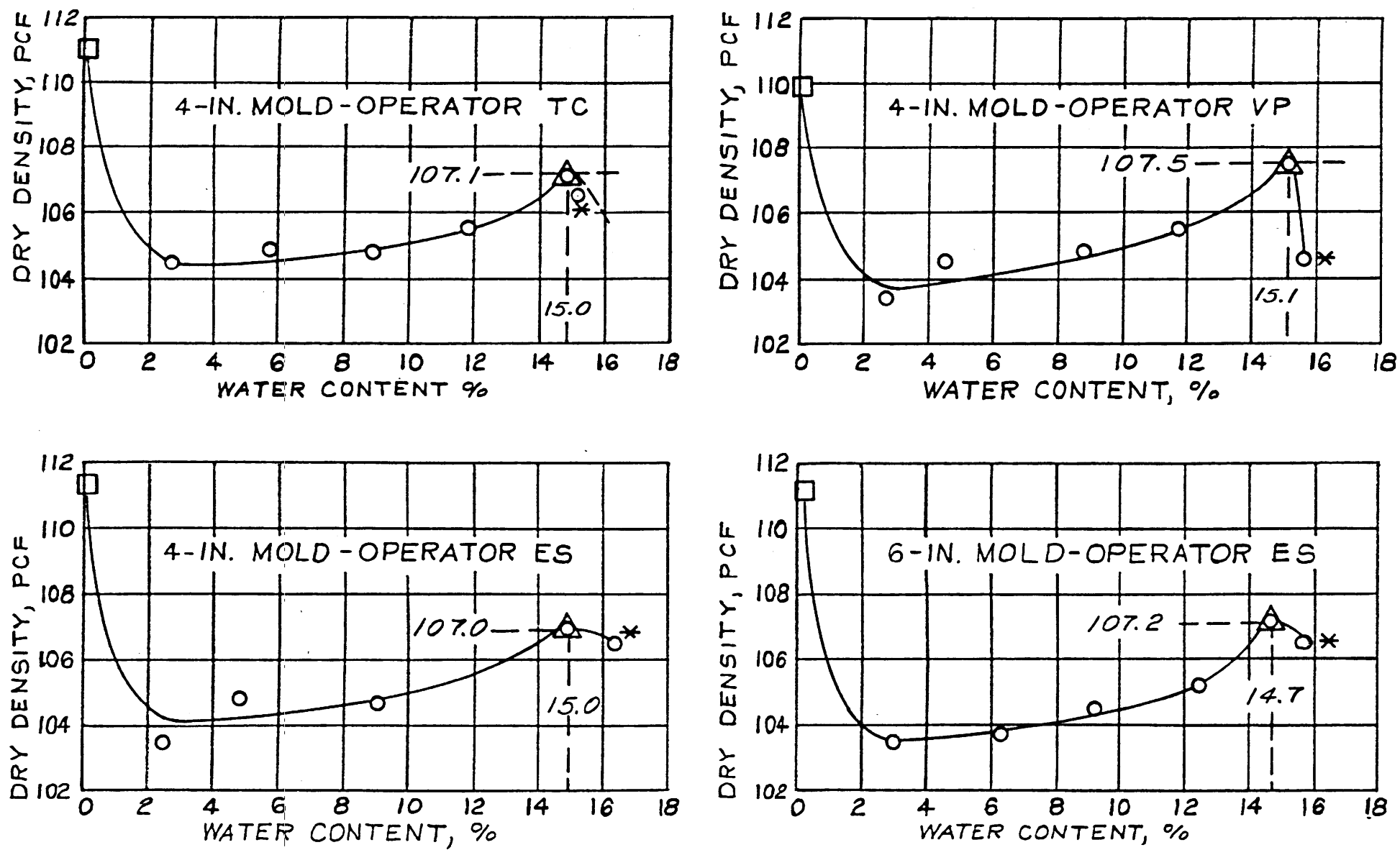

NOTES: SPECIFIC GRAVITY OF 2.70 MEASURED FOR SAND. TEST RERUN FOR CHECK. REASON FOR HIGH VALUE NOT KNOWN.

AT IIOPCF, WATER CONTENT FOR ZERO AIR VOIDS $=19.7 \%$

* free water

$\triangle$ INDICATES MAXIMUM DENSITY aT "OPTIMUM" w

$\square$ INDICATES MAXIMUM DENSITY OF DRY MATERIAL ( -0 TO $0.2 \%$ ) 


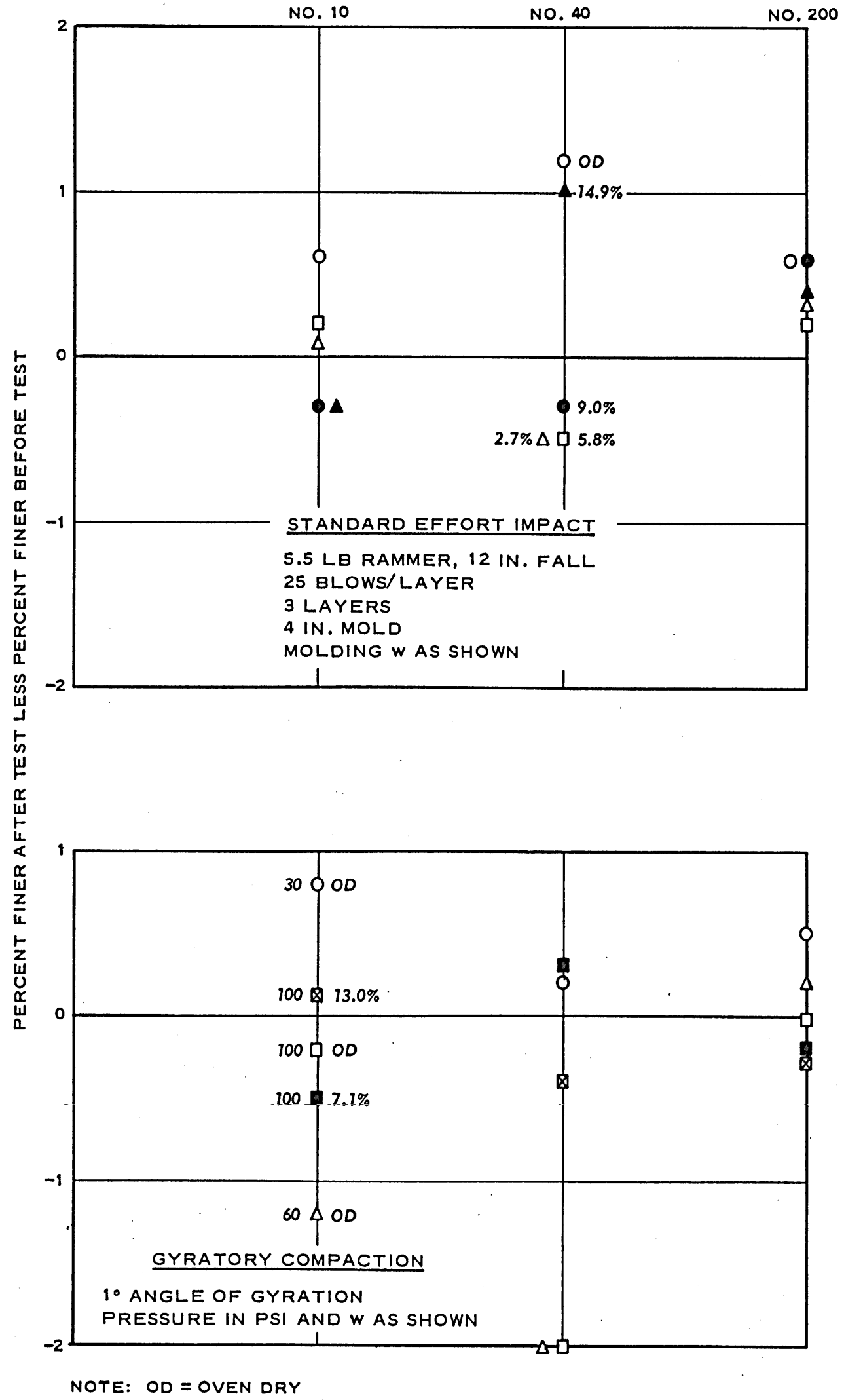

Fig. 7. Effect of compaction on gradation, Hopkinton-Everett sand (SP) 


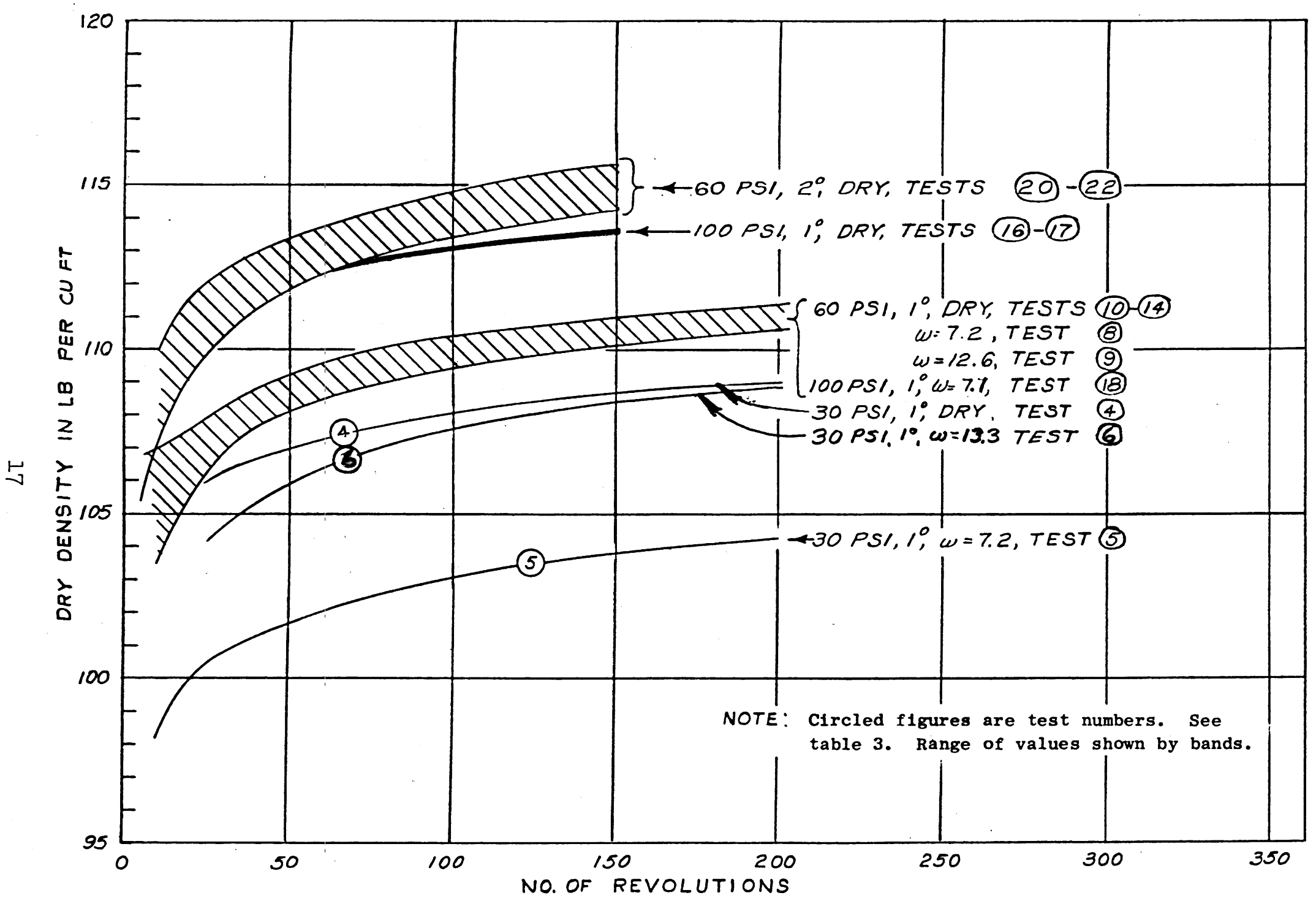

Fig. 8. Gyratory compaction curves, Hopkinton-Everett sand (SP) 
conducted before and after gyratory compaction indicated that no significant degradation of particles occurred during the tests (see fig. 7). The small variations in percent passing any one screen appeared to be random scatter.

24. As can be seen in fig. 8, the density of specimens compacted using an angle of gyration of 1 deg under a pressure of 60 psi was relatively insensitive to change in water content. On the other hand, under the low vertical pressure of $30 \mathrm{psi}$, the density (103.6 pcf) at the intermediate water content was substantially lower than those of the dry and wet material ( 107.9 and 108.1 pcf, respectively).

25. Tests by different operators and repeated tests by the same operator indicated excellent reproducibility of results, the greatest variation being $3.2 \mathrm{pcf}$ for tests using l-deg gyratory angle and 100-psi vertical pressure (see table 4). The densities obtained on dry specimens using various angles of gyration and two vertical pressures can be readily compared in table 4. The highest densities were obtained on dry material using 2-deg gyratory angle and 60-psi vertical pressure; these densities averaged 115.0 pcf or 6.2 pcf higher than the average density obtained using a 1/2-deg angle and 60-psi pressure. However, if a 2-deg gyratory angle and 100-psi pressure had been used, even higher densities might have been obtained.

26. Summary. The differences in densities obtained by three different operators ranged from $0.3 \mathrm{pcf}$ (in the MVT test) to $1.9 \mathrm{pcf}$ (in the STD tests on dry material). Except for these latter tests, the differences were generally about $I$ percent of the average or less. Highest densities were obtained in the MPVD test (average $117.2 \mathrm{pcf}$ ), followed closely by the MVT test (average $115.5 \mathrm{pcf}$ ) and the GC test with 2-deg gyratory angle and 60-psi vertical pressure (average $115.0 \mathrm{pcf}$ ). Densities of other tests ranged down as low as 107.2 pcf.

West Thompson sand (SW)

27. Three MPVD tests, three MVT tests, and nine GC tests were performed on the West Thompson sand (SW) to provide additional information on a gradation intermediate between the Hopkinton-Everett sand (SP) and the Painted Rock sandy gravel (GW). The GC tests were performed under a 
vertical pressure of 60 psi at gyratory angles of $1 / 2,1$, and $2 \mathrm{deg}$. The three tests at each angle of gyration were performed by different operators.

28. The test data for all laboratory compaction tests on the West Thompson sand are summarized in table 5. A summary of the densities for all tests is shown in table 6. The GC test curves are shown in fig. 9. From table 6 it can be noted that equally high average densities were obtained from the MPVD method, MVT method, and GC method (at a gyratory angle of $2 \mathrm{deg}$ under a vertical pressure of $60 \mathrm{psi}$ ). The least variation in density ( $0.6 \mathrm{pcf}$ ) for three tests by different operators was obtained in the MVT test, and the greatest variation ( $3.4 \mathrm{pcf}$ ) was obtained in the MPVD test.

Painted Rock sandy gravel (GW)

29. Tests other than GC. Results of compaction tests performed on the sandy gravel are summarized in table 7, and densities obtained are summarized in table 9. Ten STD tests, five PVD tests, four MPVD tests, eight VT tests, and three MVT tests were performed.

30. Seven of the STD tests were performed using a 10-1b rammer, and three were performed using a 5.5-1b rammer. The compaction curves for these tests are shown in fig. 10.

31. Gradation tests conducted on samples from one impact compaction test after compaction to determine the extent of particle degradation indicated that the apparent increase in material passing any one sieve size did not exceed 1 percent of the total sample by weight (see fig. II). Here, as in similar comparisons for Hopkinton-Everett sand (see fig. 7), random scatter was evidenced by the data.

32. For the three tests using the 10-1b rammer, the average of the maximum densities was $136.0 \mathrm{pcf}$, and the greatest difference between maximum densities for individual tests was 1.1 pcf. All of these tests were performed by the same operator. The optimum water content for the impact tests using the 10-1b rammer was 8.0 percent without variation. The impact test on the ovendry sample produced a density of 126.9 pcf, about 8 to 9 pcf less than the maximum densities obtained at optimum water content of 8.0 percent. 


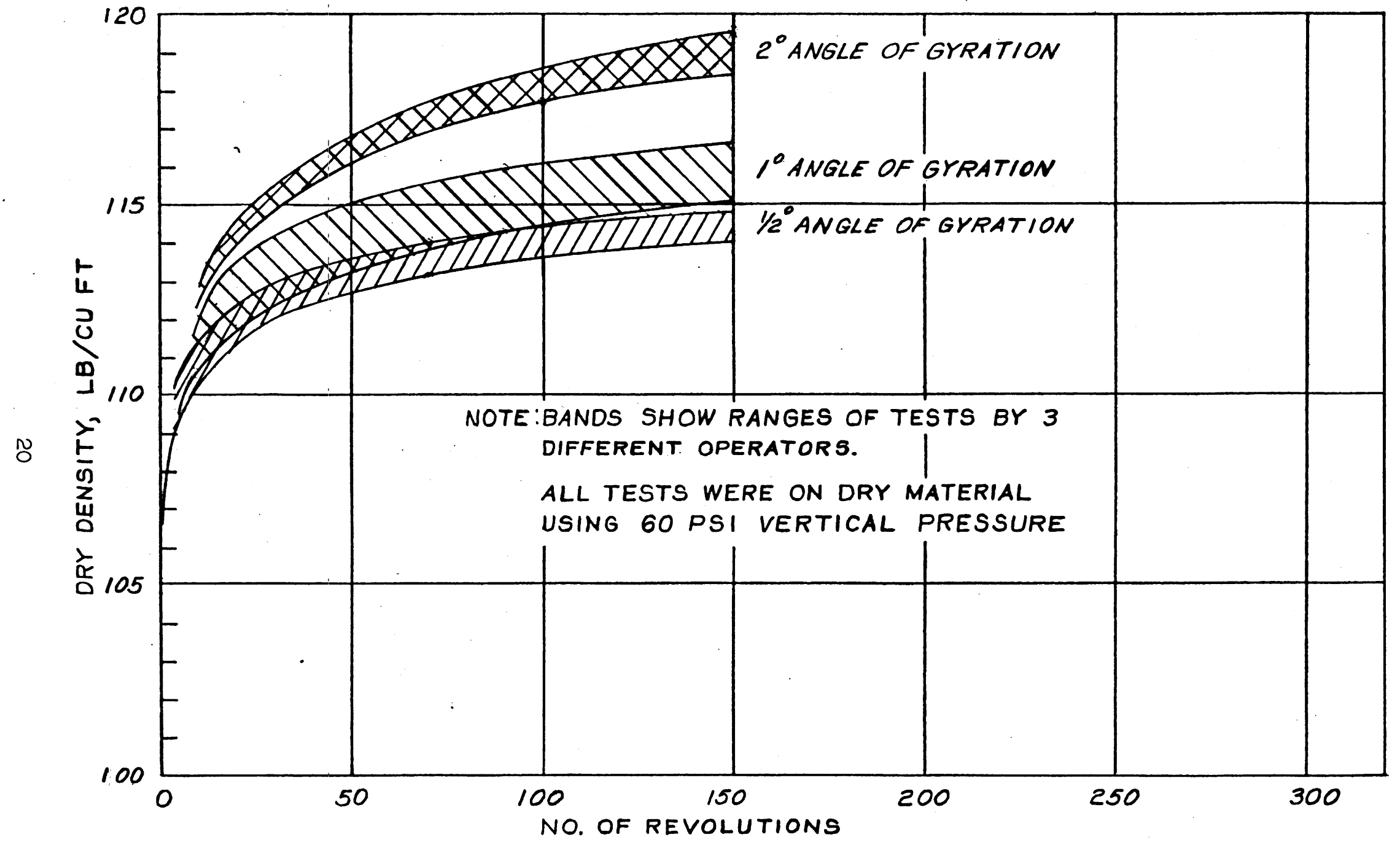

Fig. 9. Gyratory compaction curves for West Thompson sand (SW) 

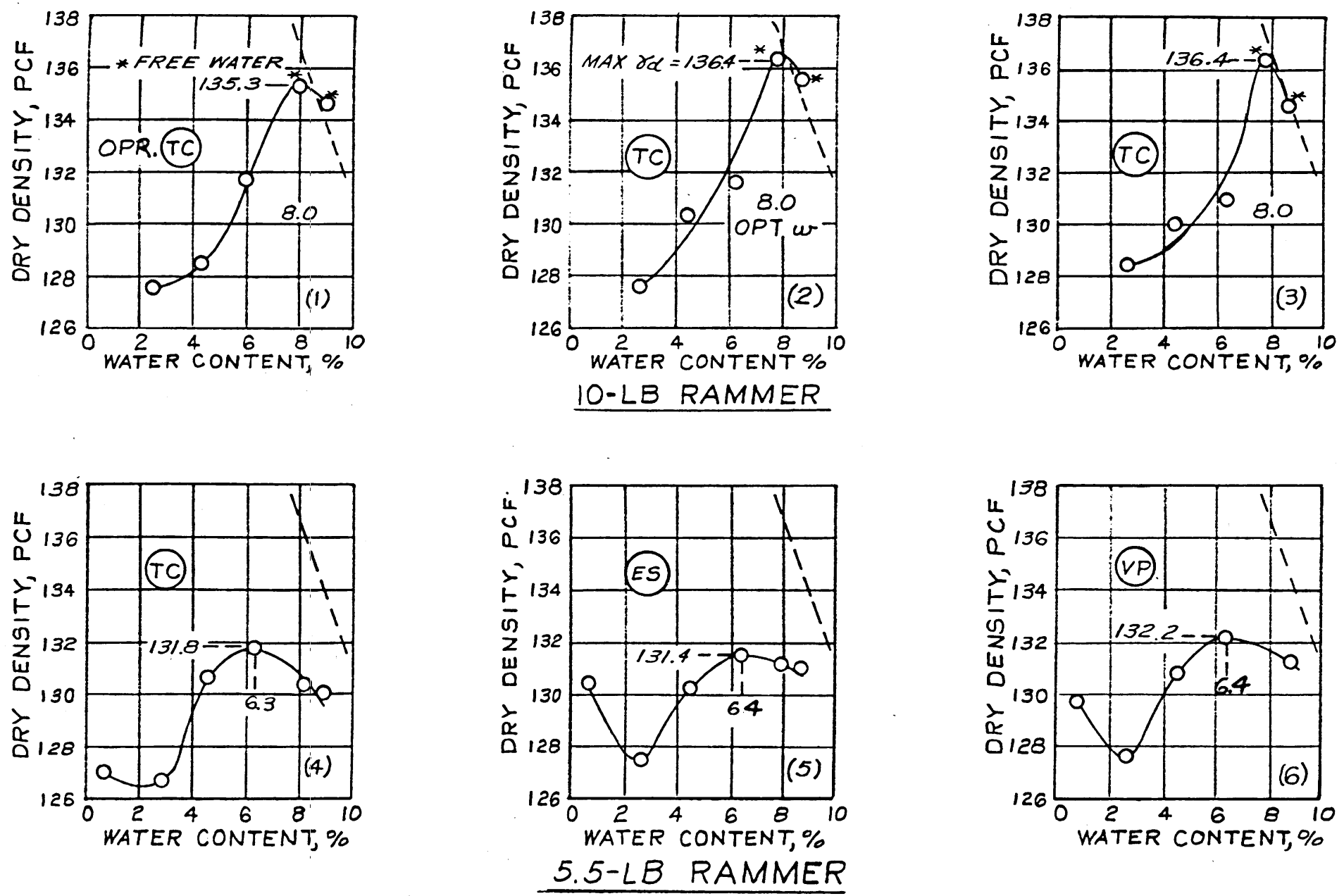

NOTES: 1. MATERIAL WAS MINUS 3/4-IN. FRACTION WITH REPLACEMENT OF OVERSIZE MATERIAL.

2. EFFORT RANGED FROM 12,000 TO 12,320 FT-LBS/CU FT.

3. NUMBERS IN PARENTHESES DENOTE ORDER LISTED IN TABLE 7.

Fig. 10. Impact compaction curves, Painted Rock sandy gravel (GW) 
SIEVE SIZE

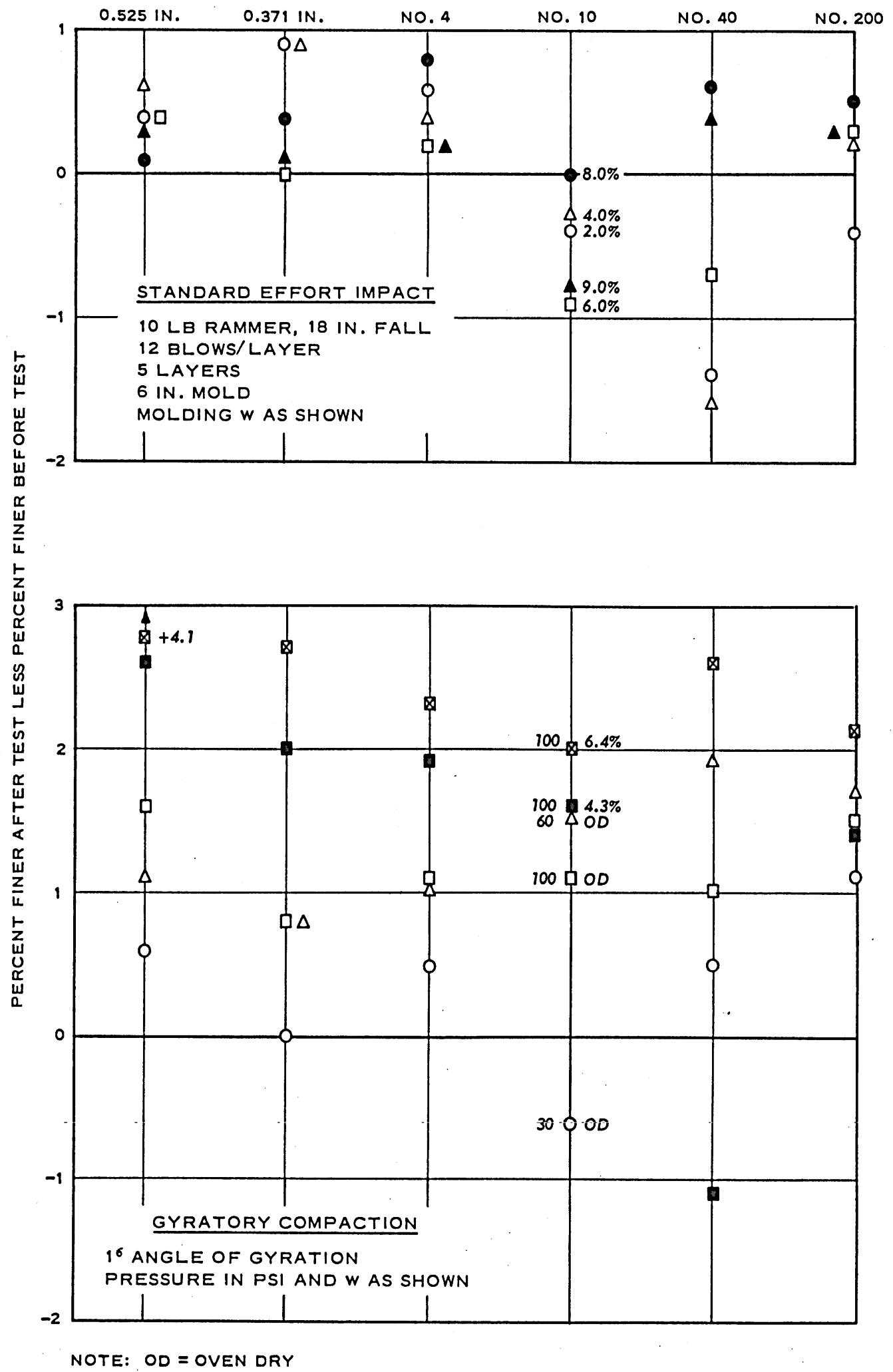

Fig. 11. Effect of compaction on gradation, Painted Rock sandy gravel (GW) 
33. The impact compaction tests on the sandy gravel using the 5.5-1b rammer produced an average maximum density of $131.8 \mathrm{pcf}$, or about 3 pcf less than the average maximum density obtained using the 10-1b rammer, even though the same total energy was used. The optimum water content for tests with the 5.5-1b rammer was 6.4 percent. The greatest difference between maximum densities for individual tests with the 5.5-Ib rammer was $0.8 \mathrm{pcf}$; these tests were performed by three different operators.

34. The densities obtained on ovendry material having a maximum particle size of $2-1 / 2$ in. averaged $133.7 \mathrm{pcf}$ in the five PVD tests, with a maximum difference of 8.1 pcf for individual tests. The first three PVD densities shown in table 7 are listed in the order in which the tests were performed by the same technician. Although new material was used for each sample, the density increased each time, with the maximum difference being $5.4 \mathrm{pcf}$, which is about the same as the maximum difference for the tests performed by different technicians. The average density for the four MPVD tests was $137.8 \mathrm{pcf}$, with a maximum difference in density between individual tests of 4.0 pcf. Each test was performed by a different operator.

35. VT tests were performed on ovendry samples of the minus 2-1/2in. material using a 12.25-in.-diam mold. Preliminary tests showed that great care had to be taken to prevent segregation in placing this material in the mold. Otherwise, the densities obtained were low and could not be duplicated. Vibration times ranged from 8 to $15 \mathrm{~min}$.

36. Samples of the well-graded sandy gravel were prepared by placing the required weight of each fraction in a pan. Since the particle sizes ranged up to $2-1 / 2$ in., it was found that segregation would occur during placement in the mold, unless the prepared sample was spread out in a thin layer in the pan with the larger particle sizes uniformly distributed, and care was taken to ensure that each scoop placed in the mold contained a uniform mixture of all particle sizes. Initial vibratory tests performed on material not placed as described gave maximum densities averaging about 10 pcf less than those for carefully placed material.

37. The three MVT tests conducted by different operators produced 
densities that ranged from 131.9 to 136.1 pcf and averaged 133.7 pcf. Comparison in table 7 of the densities obtained for the five compaction methods (other than the gyratory) used on the sandy gravel indicates that the most consistent results were obtained with the STD method. The least consistent results were obtained with the PVD method, in which the maximum difference between individual densities was about $8 \mathrm{pcf}$, and there were large variations in results of tests conducted by the same operator. There were also large differences in results of the MPVD and MVT tests, though only about half of that for the PVD test.

38. GC tests. The GC tests were performed on the minus 3/4-in. portion of the sandy gravel (GW), with the plus 3/4-in. fraction replaced by an equal amount of material passing the 3/4-in. sieve and retained on the No. 4 sieve. The gradation curve for the material tested corresponded very closely with that used in the STD tests, as shown in fig. 1.

39. Twenty tests were conducted on material prepared at three different initial water contents: (a) about ovendry, (b) 4 percent, and (c) about 8 percent (corresponding to optimum water content for STD compaction). The tests were conducted at vertical pressures of 30,60 , and $100 \mathrm{psi}$ and angles of gyration of $1 / 2,1$, and $2 \mathrm{deg}$. A number of tests with the same testing conditions were performed by different technicians to determine the effect that using different operators would have on the test results.

40. Curves of dry density versus number of gyratory revolutions for tests on the sandy gravel are shown in fig. 12. A summary of the gyratory test results is given in table 8, and densities are further summarized in table 9. Water contents determined after the tests were about 0,4 , and 7 percent of dry weight for the three different water content groups (free water was noted in every case for the wetter group of specimens). 41. Fig. 13a demonstrates the effect of water content and vertical pressure upon compacted density in tests conducted by the same technician using an angle of gyration of $1 \mathrm{deg}$. The compacted density is shown to be greatly infíuenced by the water content, increasing on an average from 8 to $10 \mathrm{pcf}$ from the dry to the wettest condition. There were only small differences in densities obtained in tests in the same water content group 


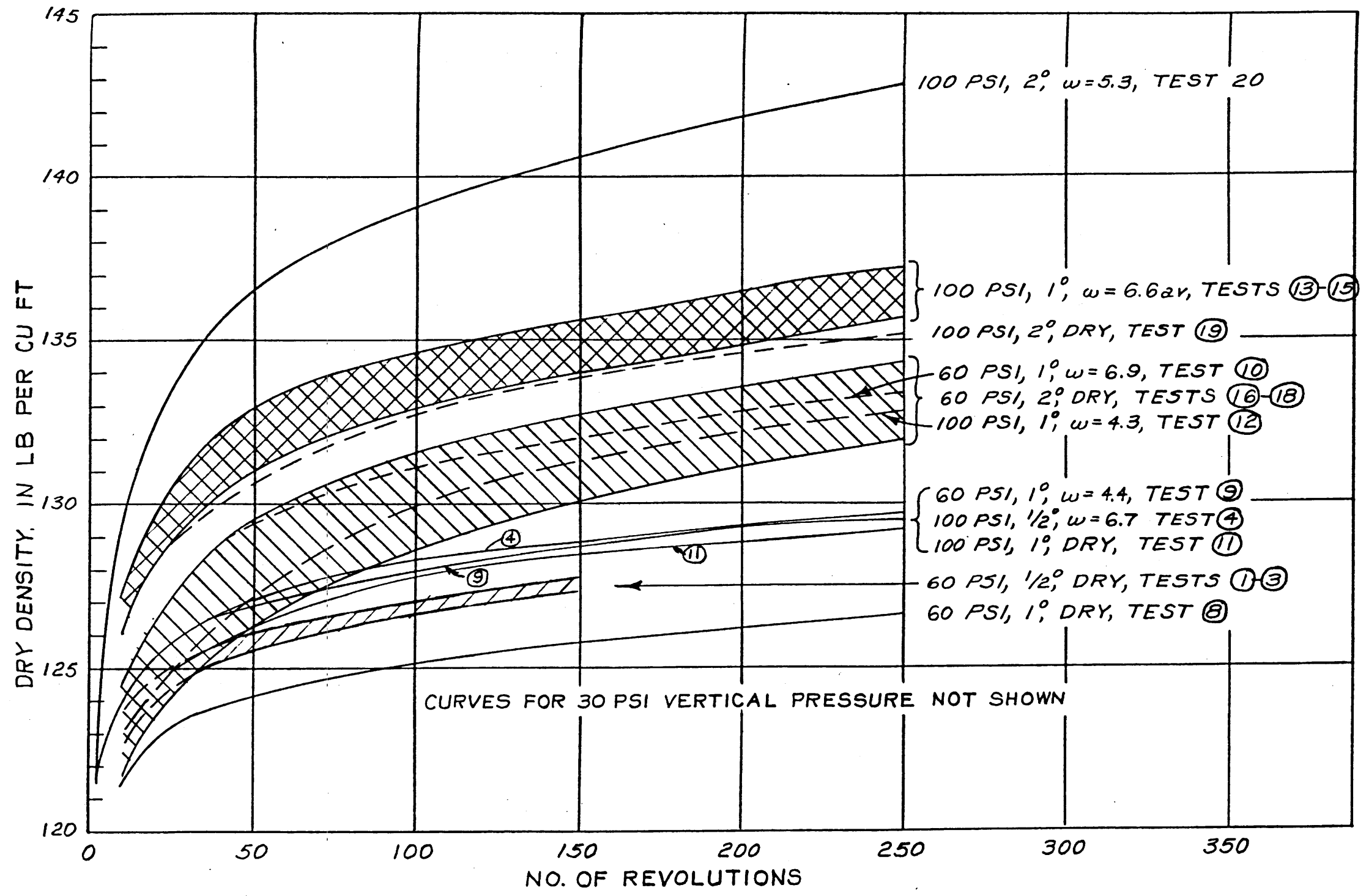

Fig. 12. Gyratory compaction curves, Painted Rock sandy gravel (GW) 


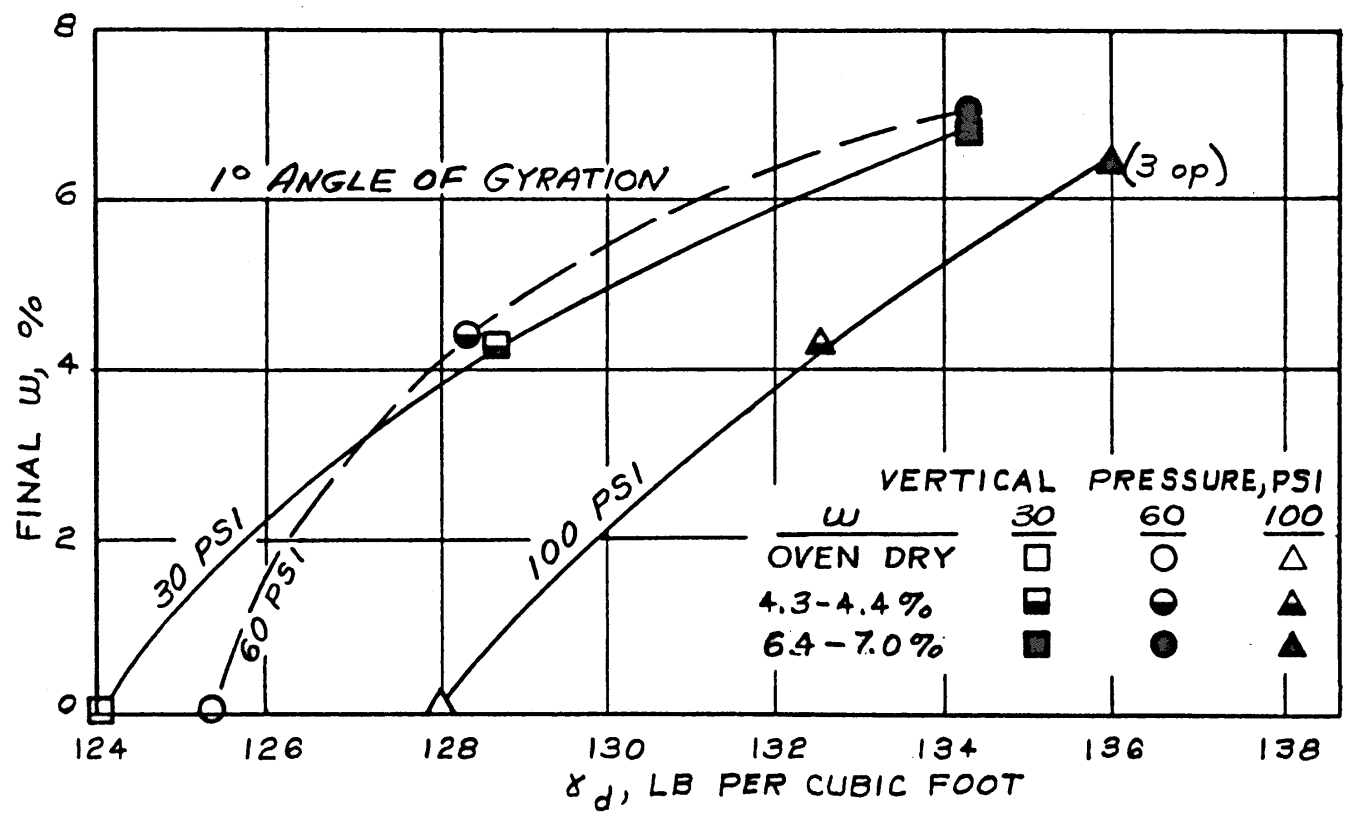

2. EFFECT OF WATER CONTENT AND VERTICAL PRESSURE

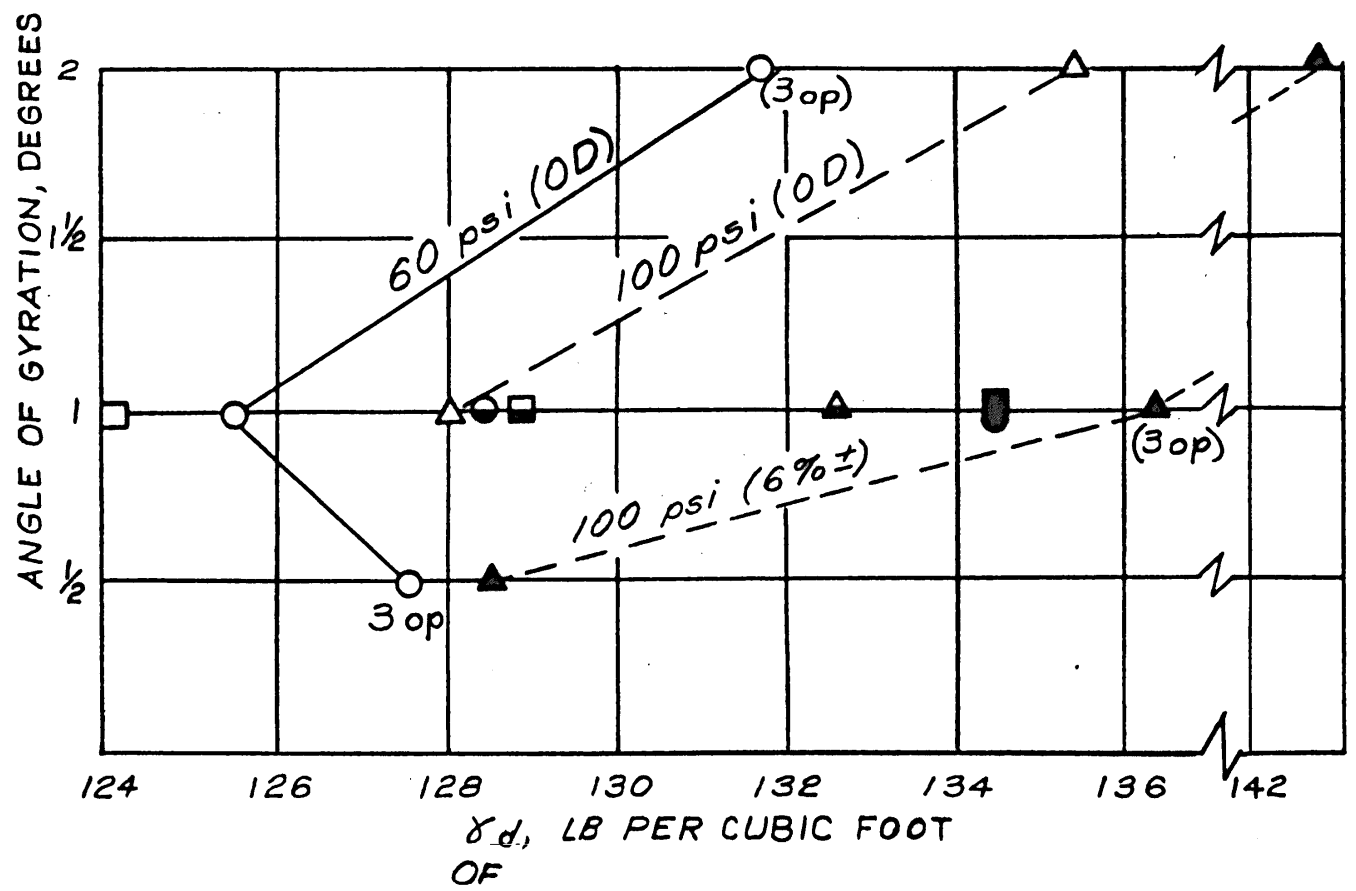

b. EFFECT OF ANGLE ${ }_{\wedge}$ GYRATION AND VERTICAL PRESSURE NOTE: ALL TESTS BY OPERATOR ES EXCEPT THOSE NOTED AS "3op", WHICH ARE AVERAGES OF TESTS BY 3 OPERATORS

Fig. 13. Effects of various factors on densities in gyratory compaction tests, Painted Rock sandy gravel (GW) 
for the 30- and 60-psi pressures using an angle of gyration of 1 deg. The greatest difference was 1.4 pcf for the dry specimens, and the average difference was only $0.4 \mathrm{pcf}$. On the other hand, the tests using 100-psi pressure showed considerably higher densities than those using lower pressures, averaging 3 pcf higher. Thus, while the GC test density for this material appears to be affected most by water content, vertical pressure and angle of gyration are also important factors (fig. 13b). 42. The resulting densities for tests on the dry specimens conducted with a vertical pressure of 60 psi by different operators were within 1 pcf for an angle of gyration of $1 / 2 \mathrm{deg}$, while for $2 \mathrm{deg}$, the difference in densities amounted to 2.7 pcf.

43. Varying the angle of gyration had a large effect on the compacted densities of the sandy gravel. Fig. 13b shows that increasing the angle of gyration from 1 to 2 deg resulted in a density increase of about 7 pcf for the dry condition under vertical pressures of 60 and 100 psi, and about the same for the 6 percent w condition under $100 \mathrm{psi}$. The effect of reducing the angle of gyration from 1 to $1 / 2$ deg was not clearly defined in the tests, as the dry material increased about 2 pcf in density under a vertical pressure of $60 \mathrm{psi}$, and the wettest material decreased about 8 pcf under a vertical pressure of 100 psi.

44. Five pairs of gradation tests were conducted on the material before and after compaction (see fig. 11). After compaction, the percent of material passing was generally 1 to 2 percentage points more than that before compaction. While random scatter can be expected in replicate tests on the same material, the consistent trend of the data suggests there was a slight amount of degradation of particles during gyratory compaction, but it was so small that it had no practical significance.

45. Summary. As show in table 9,- the highest densities using minus 2-1/2-in. material were obtained in the MPVD and the VT tests ( 137.8 and 138.5 pcf, respectively). The average density obtained in the MVT test was 133.7 pcf, about 4 pcf lower. Densities ranging from 98.2 to 99.0 percent of MPVD density were obtained on minus 3/4-in. material with replacement in the STD tests using the 10-1b rammer on material at optimum water content, and in two GC tests using 100-psi pressure (one with 
ovendry material and using a 2-deg gyratory angle, and one at 6.6 percent water content and using l-deg gyratory angle).

46. The least variation in densities with different operators was obtained using minus 3/4-in. material with replacement in two of three sets of GC tests and in the STD tests $(0.4$ to 1.1 pcf). The greatest variation using minus 2-1/2-in. material was in the PVD test ( 8.1 pcf). Variation in densities of MPVD and MVT tests conducted by different operators was about 4 pcf. The differences in results for the materials with different maximum particle sizes reflect the difficulty of preparing uniform specimens with the material having particles up to $2-1 / 2$ in., as discussed in paragraph 36.

Summary of test results

47. Fig. 14 shows the range of densities and average density obtained through use of the principal test methods on the three soils. The MPVD test generally produced the highest densities for all three soils, although these densities are sometimes equaled or slightly exceeded on a given soil using other test methods. The MVT and the GC tests gave densities for the three soils that average about 98 percent of the MPVD results. Also, the MVT and GC tests showed less spread of results than the MPVD tests. The STD test using the standard 5.5-1b rammer gave low density values for the two soils tested (SP and GW), but a density value of 98.6 percent of MPVD when a 10-Ib rammer was used. The STD tests on wet material did, however, consistently show a much smaller range of densities than any other tests. 


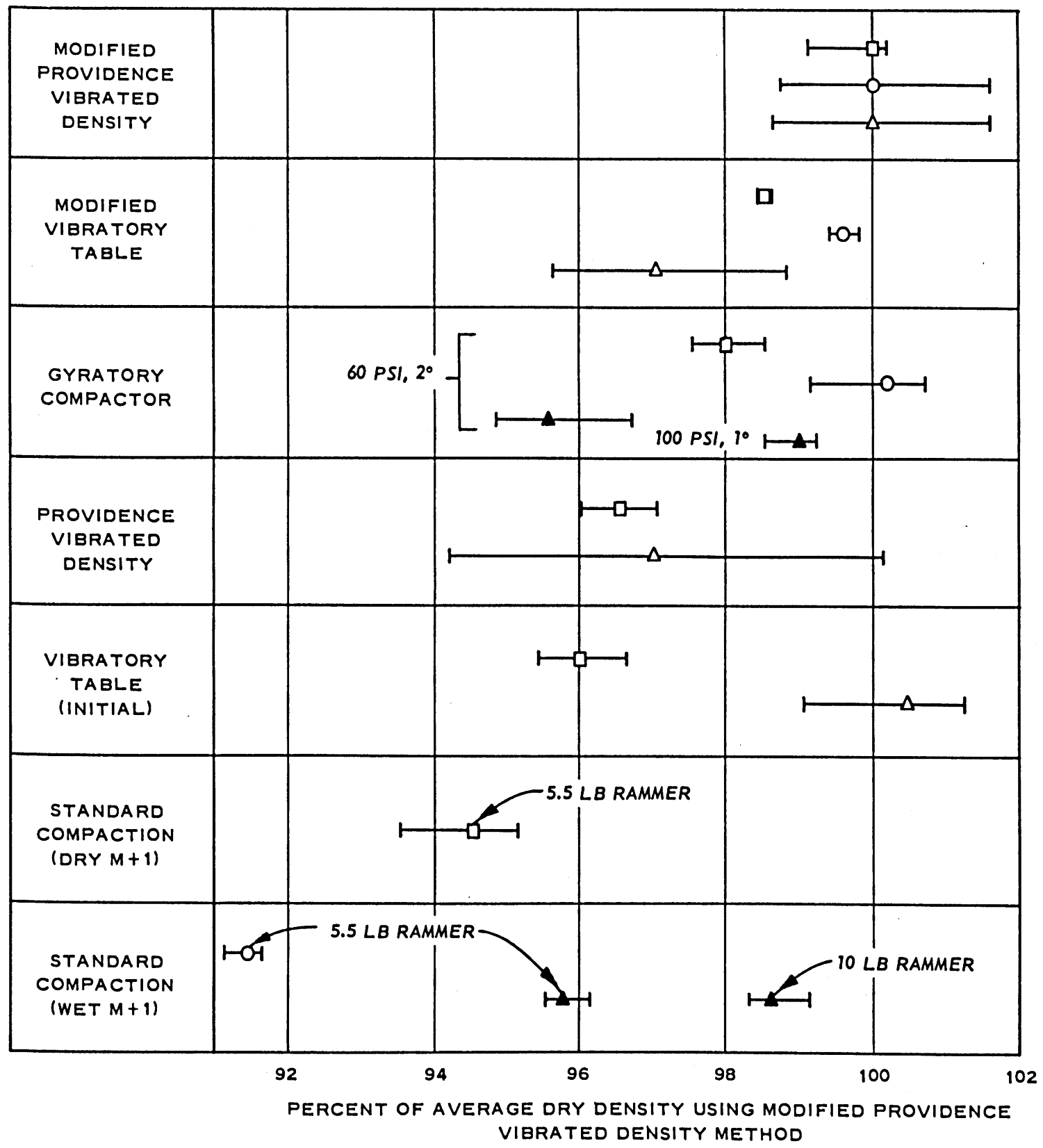

\section{LEGEND}

O HOPKINTON-EVERETT SAND, SP

D WEST THOMPSON SAND, SW

$\triangle$ PAINTED ROCK SANDY GRAVEL, GW - 2-1/2 IN.

$\triangle$ PAINTED ROCK SANDY GRAVEL, GW - 3/4 W/REPL MINIMUM

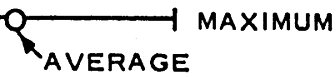

Fig. 14. Comparison of densities obtained from various compaction methods 


\section{Survey of CE Offices}

48. The Divisions and Districts of the Corps of Engineers were surveyed during FY 1960 to determine their construction experience with cohesionless materials, including the types of laboratory compaction tests used, field compaction procedures, and methods used in field density control testing. Data received on 37 soils are presented in table 10. Data from a number of other projects were received, but these are not included for a number of reasons, but primarily because gradation data for establishing the similarity of field materials with laboratory samples were not included. In 25 of the 37 items listed in table 10, the individual laboratory results could not be paired with the individual field test results on the same soils. The percent compaction values shown in the table for these soils were arbitrarily computed by comparing the lowest field value to the lowest laboratory value reported and the highest field value to the highest laboratory value reported. Furthermore, in some instances the laboratory compaction tests were conducted on specimens from which significant portions of large particles had been scalped; comparisons of field densities on unscalped material with unadjusted results of the laboratory tests on scalped material are, of course, subject to considerable error.

49. Comparisons of field and laboratory compaction data for the Hopkinton-Everett sand (SP), the West Thompson sand (SW), and the Painted Rock sandy gravel (GW) used in the WES laboratory investigations described in Part II are discussed in paragraphs 52-70.

50. Fig. 15 shows the ranges of field densities for each project expressed in percent of laboratory density values reported by the Divisions and/or Districts and grouped according to method of compaction and soil type. Gradation of materials ranged from sandy gravels to silty sand, and projects within each compaction test group are arranged in the order of decreasing coarseness of material. In general, three principal methods were used by the Corps offices in compaction tests on cohesionless 


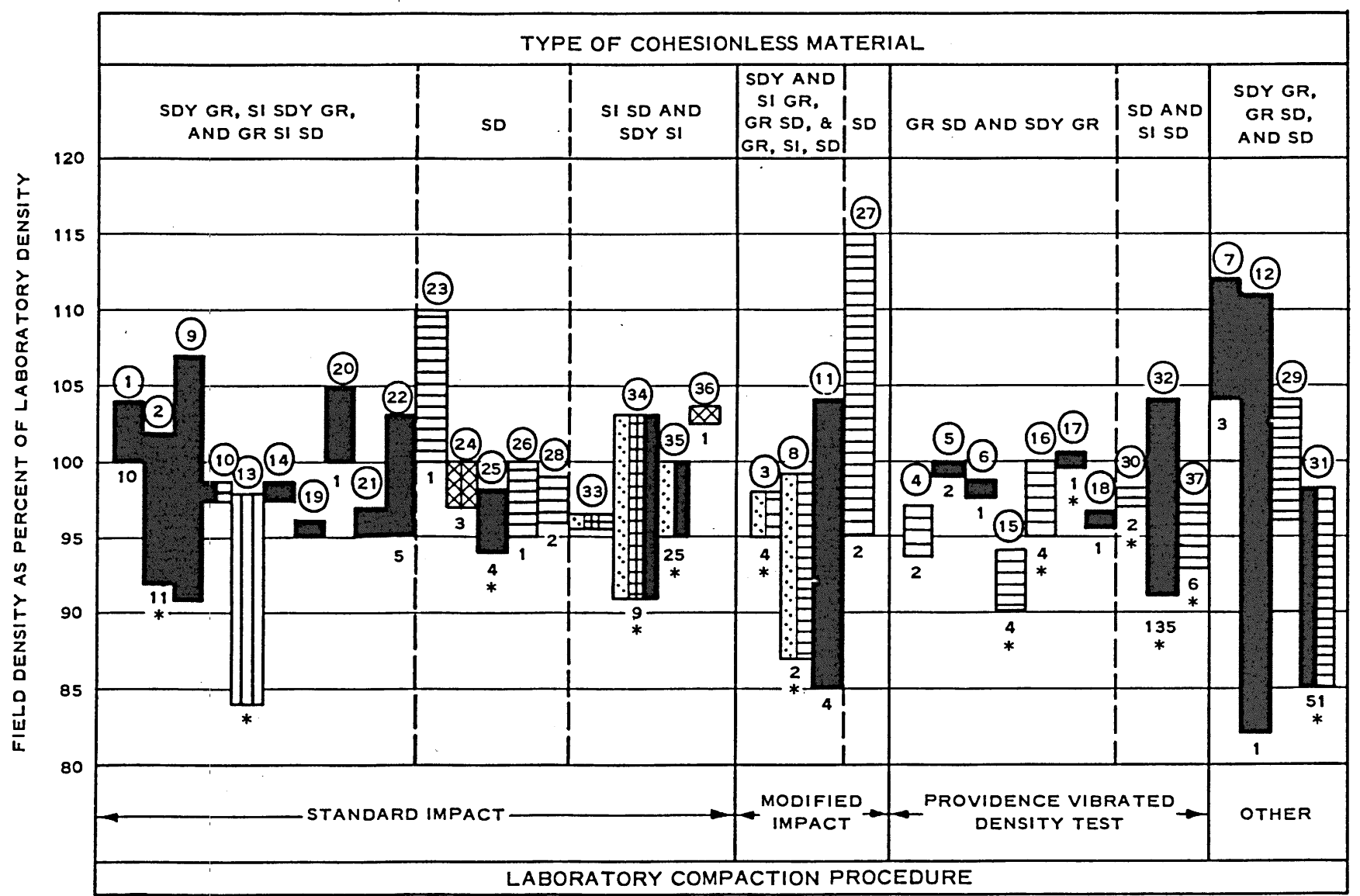

\section{LEGEND}

RUBBER-TIRED ROLLER CRAWLER TRACTOR

SHEEPSFOOT ROLLLER

HAULING EQUIPMENT GRID ROLLER

STEEL-WHEEL ROLLER

VIBRATING EQUIPMENT
NOTES: NUMBERS ABOVE BARS REFER TO PROJECT NUMBERS IN TABLE 10

NUMBERS BELOW BARS INDICATE NUMBER OF LABORATORY COMPACTION TESTS CONDUCTED WHEN KNOWN COMBINATION OF SYMBOLS INDICATE COMBINATION OF EQUIPMENT USED

* indicates most valio data (note 4, table 10)

Fig. 15. Field densities as percent of laboratory densities 
materials--standard impact compaction, modified impact compaction, and Providence vibrated density. In some cases, variations of the impact and Providence procedures were being used; these include rodding the specimen and pounding the mold with sledge hammers or other heavy objects. As shown in fig. 15, field compaction was accomplished with a wide variety of equipment: rubber-tired rollers, tractors, sheepsfoot rollers, grid rollers, steel-wheel rollers, hauling equipment, and vibrating equipment.

51. For the data shown in fig. 15, the ratios of field densities to corresponding laboratory densities had the least spread when the Providence vibrated density procedure was used. Corresponding field densities ranged from 90 to 104 percent of the Providence vibrated densities, whereas with the other methods the range of field densities in terms of laboratory results was much broader, ranging from 82 to 115 percent. Field densities expressed as percentages of laboratory densities showed no consistent relations with field compaction procedures, maximum particle sizes, or gradation analyses.

\section{Comparison of Laboratory Test Results with} Field Data on Materials Tested at WES

52. As previously stated, one objective of this investigation was to determine a laboratory compaction test procedure that will produce densities that can be achieved economically in the field with conventional field compaction equipment and at which the soil will have satisfactory engineering properties. The following paragraphs present field compaction data on the Hopkinton-Everett sand (SP), West Thompson sand (SW), and Painted Rock sandy gravel (GW) and a comparison of the densities obtained in the laboratory with densities measured in the field on materials with gradations similar to those of the materials used in the laboratory tests. Hopkinton-Everett sand (SP)

53. The sand (SP) used in the WES laboratory investigation was obtained from borrow area D, which was used for the construction of dike P-I at the Hopkinton-Everett project. Construction control data for dike P-I furnished by the New England Division (NED) included description of the methods of field compaction and density sampling and the results of 135 
field density determinations, 135 Providence vibratory density tests, 97 gradation tests, and 74 one-point standard impact determinations.*

54. Dike P-I, which contains approximately 254,000 cu yd of material, consists of a large pervious section with an upstream inclined impervious zone. The material used in the dike was excavated, hauled, and spread with 18-cu-yd scrapers. The scrapers spread the material in 2- to 4-in. layers until a 9- to 12-in. loose lift had been attained. Additional spreading was accomplished with graders. The material was wetted to a saturated condition (defined as the presence of free water in the imprints of vehicle tires) by sprinkling from two motorized watering units that operated continuously during placement and compaction. Approximately 18 gal of water was placed for each cubic yard of fill. In general, material for the pervious section was placed during rainy weather when the impervious fill could not be worked. Compaction of the pervious material was accomplished by four or six coverages of the 9- to 12-in. lifts with a 50-ton, 4-wheel, rubber-tired roller, using 85-psi tire pressure:

55. Field density tests were performed on material one lift below the surface using the water balloon method. Providence vibrated density tests were performed on ovendry material obtained from each field density sample, and the resulting density was compared with the measured inplace density to determine percent compaction. Samples of material also were taken from locations adjacent to the point at which field density tests had been conducted for a one-point standard effort compaction test to obtain data for comparison with standard effort compaction test curves and to provide information relating percent compaction at field moisture versus percent compaction based on the Providence test. The one-point compaction tests were performed on the minus No. 4 fraction, while the Providence test was performed on the total sample.

56. The maximum particle sizes of the 97 field density samples on which gradation data were obtained ranged up to $1-1 / 2$ in., and particle

* A single density determination made by applying standard impact compaction on material at field water content. 
size distribution varied over a fairly wide range. In comparing WES laboratory densities with field densities, only data on field samples whose particle size distributions were comparable to those of the sand supplied for the WES tests were used. There were only 13 of the 97 field density samples with similar gradations. The gradation of the sand used in the WES laboratory tests is shown in fig. 1 by curve number 3, and the gradation range for the 13 field density samples selected for comparison is shown by the hatched area.

57. The data for the field samples are shown in table 11. These data are listed in groups in order of increasing compaction effort, and within groups in the order of increasing percent passing the No. 4 sieve. The field densities of the 13 samples ranged from 106.8 to 125.5 pcf and averaged $116.6 \mathrm{pcf}$. Both of the widely separated end values were determined on fill from an area that received the lowest field compaction effort (four passes over a 12-in. loose lift); the three density determinations in this area averaged $114.3 \mathrm{pcf}$. The field densities for the seven samples compacted by six passes over a 12-in. loose lift ranged from 113.1 to $124.2 \mathrm{pcf}$ and averaged $116.2 \mathrm{pcf}$; the densities of six of the samples were within +2.3 and -2.4 pcf of this average. The field densities of the three samples at the highest field compaction effort of six passes over a 9-in. loose lift ranged from 118.1 to $122.8 \mathrm{pcf}$ and averaged 119.8 pcf, with a maximum difference of about 5 pcf. Fig. 16 is a plot of field densities versus densities determined by Providence vibrated density tests conducted on the sample material by NED. The plot shows that the field densities averaged about 3 pcf less than those of the Providence tests. 58. In an attempt to find reasons other than variations in compaction efforts for the wide variations in field densities, comparisons were made of dry density versus water content, percent of minus No. 200 material, uniformity coefficient, percent sand sizes (No. 4 to No. 200), and grain size for various percentage fractions. No relation appeared to exist between density and any of these parameters, with one possible exception as indicated in fig. 17 where there appears to be some tendency for density to decrease with increase in percent passing the No. 200 sieve. 


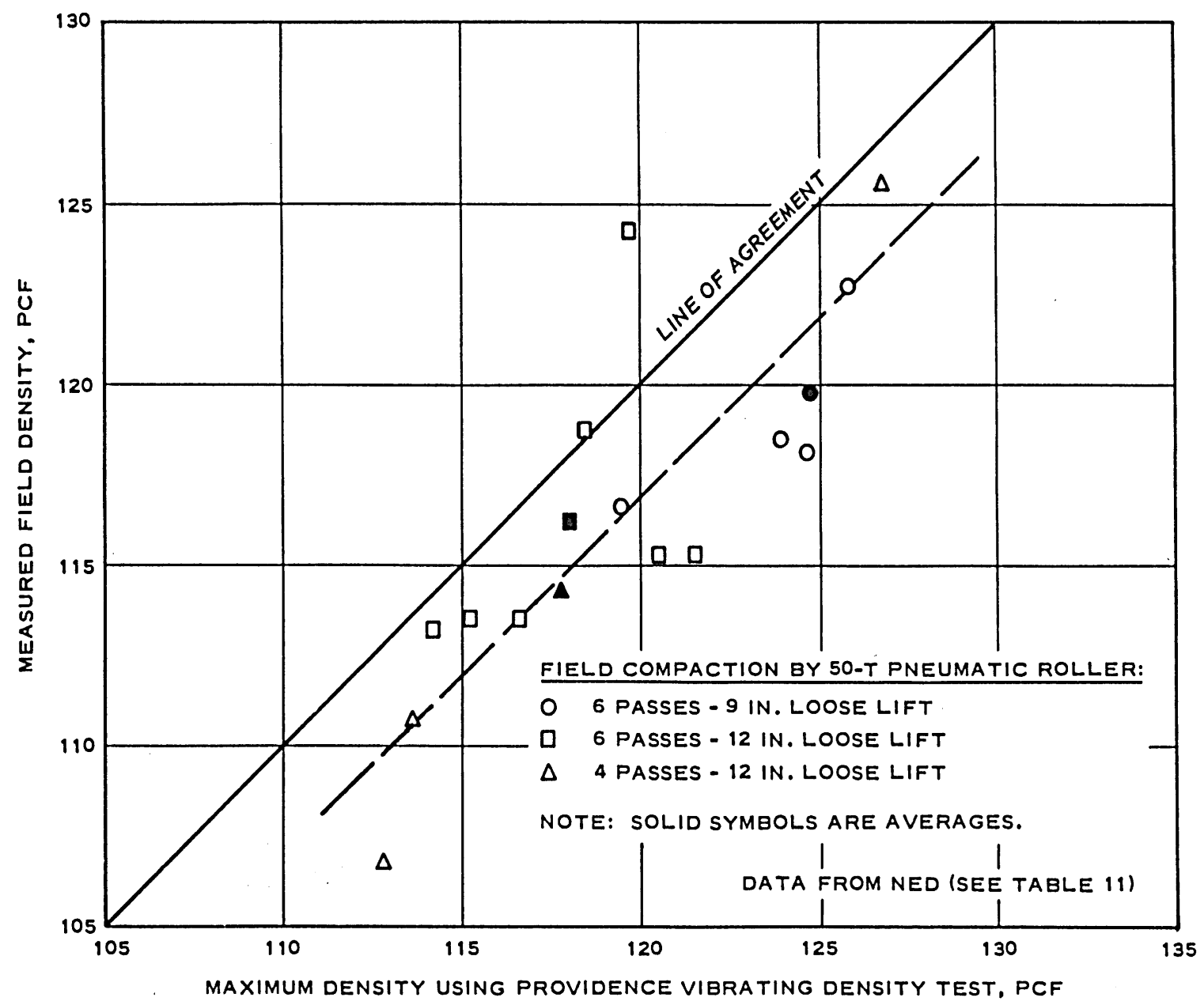

Fig. 16. Field versus PVD densities, Hopkinton-Everett sand (SP)

59. Fig. 17 shows that the average density of the 13 Providence vibrated density tests performed by NED on field density samples was about 3 pcf higher than the average in-place density. The MPVD, MVT, and GC (at 60-psi pressure and 2-deg angle of gyration) tests conducted by WES produced densities within 1-1/2 pcf of the average in-place density, but the material used in the WES tests had only a third as much minus No. 200 material as the average in-place soil, and this factor may affect the validity of direct comparison. 


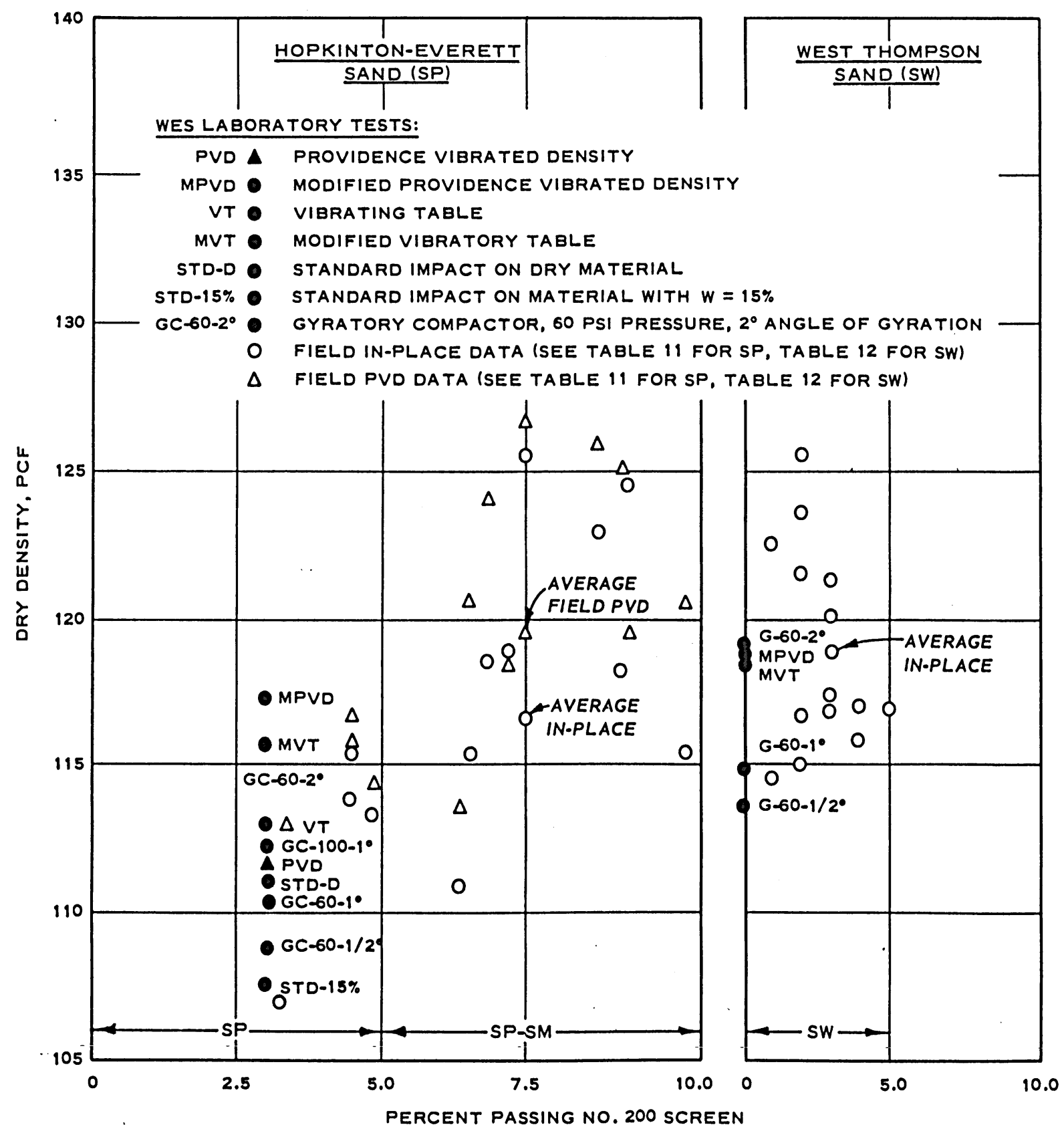

Fig. 17. Dŕy densities versus percent passing No. 200 sieve, Hopkinton-Everett sand (SP) and West Thompson sand (SW) 
West Thompson Dam sand (SW)

60. The sand (SW) used in the WES laboratory investigation was obtained from borrow area $\mathrm{C}$, a terrace deposit, which was compacted in the pervious zone downstream of the impervious zone. Field compaction control data furnished by NED contained results of 14 field density tests on sand having gradations similar to those of the sand used in the WES laboratory tests; data on these 14 field density tests were compared with data from the WES laboratory tests on the sand (SW) and are summarized in table 12. The range in gradation of the 14 field density samples is compared in fig. I with the gradation of the sand used in the WES laboratory tests.

61. The sand used in the pervious zone was excavated, hauled, and spread in approximately 4-in. layers by 16-cu-yd scrapers until an 8-in. loose lift was attained. Additional spreading of the material as necessary was accomplished using a grader. Moisture control was not required, and compaction was accomplished by three coverages of a 50-ton pneumatic roller with tire pressures of 95 psi towed by a D-8 crawler tractor at speeds of 3 to $4 \mathrm{mph}$. Field densities were determined using the water balloon method on material below a depth of 6 in. beneath the compacted soil surface. The volume of the density hole was generally in excess of I/IO cu ft. Gradations and water contents were determined for the total density samples. Providence vibrated density tests were generally performed on the material from each field density test to determine the percent compaction. When the gradation of the field density sample was the same as that of a sample on which a Providence density test had previously been performed, the percent compaction was estimated using the density value from the previous test.

62. The data from the field density samples, shown in table 12, are listed in order of increasing percent passing the No. 4 sieve. The field densities of the 14 samples ranged from 114.5 to $125.5 \mathrm{pcf}$ and averaged 118.9 pcf. The maximum particle size was $1-1 / 2$ in., and the percent of minus 3/4-in. material ranged from 96 to 98 . The percent of minus No. 4 material ranged from 77 to 87, and the percent of minus No. 200 material ranged from 1 to 5 . The reason for the wide range in field densities is not known, although a number of factors, such as nonuniform coverage by 
equipment and variations in material gradation and moisture content, could have contributed to the density variations.

63. Fig. 17 shows that the densities produced by the MPVD, MVT, and GC (at 60-psi vertical pressure and 2-deg angle of gyration) tests at WES differed within a range of only $0.7 \mathrm{pcf}$. The average density of these three tests ( $118.6 \mathrm{pcf}$ ) was only 0.3 pcf less than the average inplace density of the 14 representative field test densities.

Sandy gravel (GW),

Painted Rock Dam, Arizona

64. The sandy gravel used in the WES laboratory tests was obtained from the pervious borrow area that was the source of material for construction of the zone IV pervious sections of Painted Rock Dam. Information furnished by the Los Angeles District on material similar in gradation to that used in the WES laboratory tests included the results of three VT tests, one large-scale field density determination, and data on routine field density control tests. These data are summarized in table 13.

65. Painted Rock Dam contains approximately 7,000,000 cu yd of primarily pervious material with impervious material in a central core section. During construction, pervious material similar to the sandy gravel used in the WES tests was prewetted in the borrow area, excavated, and placed in zone IV of the embankment in 24-in. layers. Compaction was obtained with four passes of a 50-ton rubber-tired roller.

66. As part of the design of Painted Rock Dam, maximum density tests were performed in the South Pacific Division (SPD) Laboratory on samples of the pervious material. The maximum density was determined by vibrating a completely saturated specimen in a cylindrical mold under a surcharge pressure of approximately 1 psi, using vibration apparatus similar to that used in the WES laboratory tests. Maximum densities of 127, 135, and $136 \mathrm{pcf}$ were obtained in these tests on samples of zone IV sandy gravel having, gradations similar to those of the sandy gravel tested in the WES laboratory.

67. In the large-scale field density test in zone IV, $401.5 \mathrm{Ib}$ (dry weight) of material was removed from an excavated hole. The volume 
of the excavation was measured using calibrated sand in a manner similar to the conventional sand cone density method. The dry density of the total sample was $142.5 \mathrm{pcf}$. The total sample contained 11 lb (approximately 3 percent) of plus 3-in. material and $122 \mathrm{lb}$ (approximately 30 percent) of plus 1-in. material. Densities of 142.5 and 134.4 pcf were computed for the minus 3-in. fraction and the minus 1-in. fraction, respectively, assuming a specific gravity of 2.65 for the oversize material.

68. Routine field density tests were conducted using the sand cone density method. The dry weight of each field density sample averaged about $16 \mathrm{Ib}$. The water content and percent material retained on the No. 4 sieve and passing the No. 200 sieve were determined for each field density sample.

69. Fig. 18 compares the densities and gradations of 76 field compaction control tests on fill material similar to the WES-tested material with the densities obtained by the Los Angeles District in vibratory table tests and with densities and material gradation of the WES tests.

70. The WES VT and MPVD tests produced densities within 1.2 pcf of the 50-percent field density value (139 pcf) for the 76 samples. However, the three SPD vibratory table tests gave densities from 3 to 12 pcf lower. The WES STD test using a 10-1b rammer and GC tests using 100-psi pressure and 2-deg gyratory angle produced densities about 3.5 pef higher than the average density of the 76 samples. 


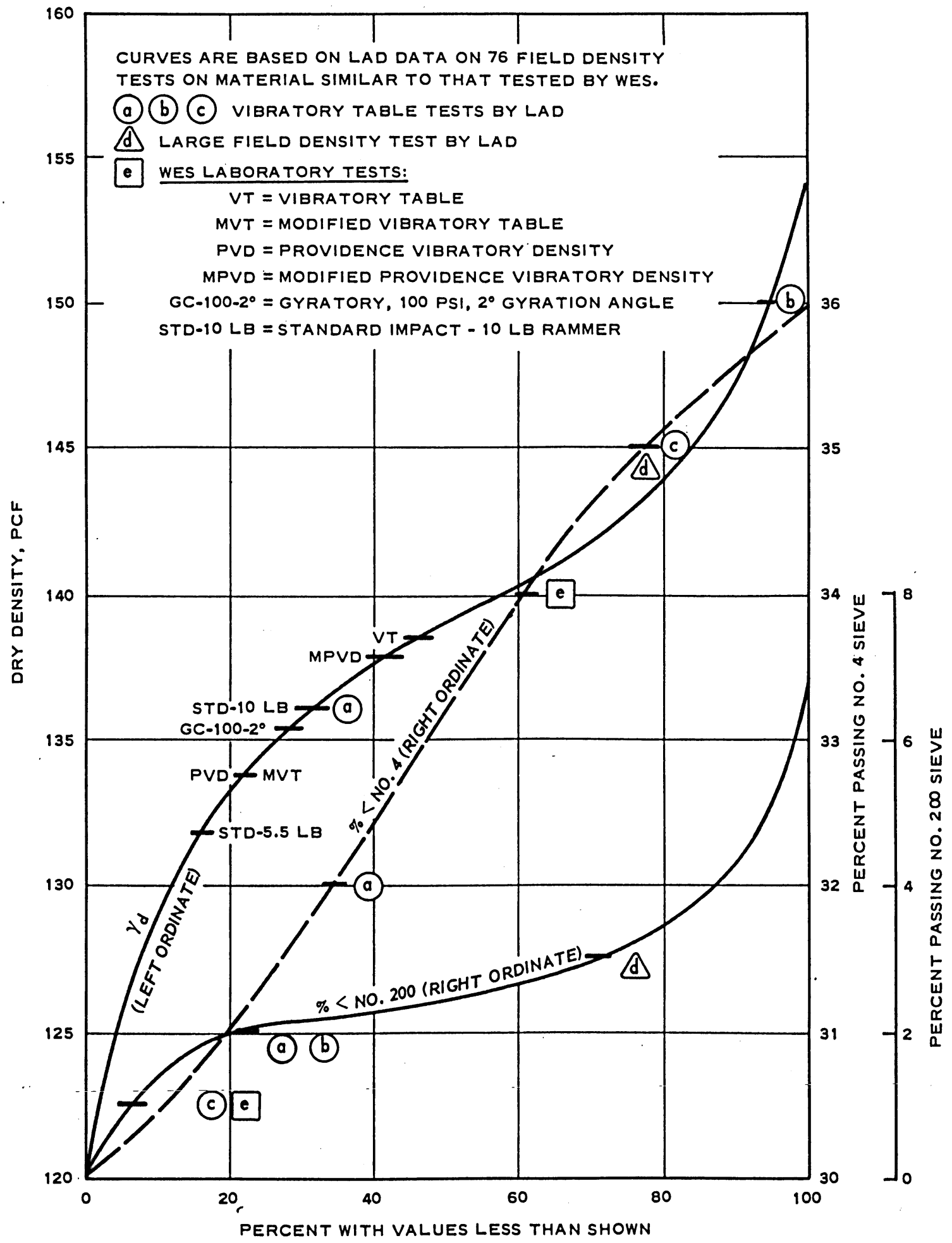

Fig. 18. Data on field density and laboratory density tests. Painted Rock sandy gravel (GW) 
71. A valid comparison of laboratory versus field density data could not be made because a statistically significant number of paired observations was not available at the time this study was made. Much field compaction data on pervious fills have been accumulated since that time. The results of these field density tests should be compared statistically with the results of companion laboratory control density tests for the pervious fills being placed in Corps of Engineers projects.

72. The wide range of density values in replicate tests on the sandy gravel (GW) with 2-l/2-in. maximum size indicates the difficulty of placing well-graded material with large particle sizes into test molds in a consistent manner.

73. The flexibility of the gyratory compactor in reproducing desired density values within close limits offers certain advantages. There is no question but that the gyratory compactor can be made to produce any desired density up to and above those attained by the other compaction methods. A definite need exists for further study to develop an optimum procedure for the gyratory compactor to produce densities matching desired field densities for various granular materials. Emphasis should be placed on a procedure utilizing a higher gyratory angle (say $2-1 / 2 \mathrm{deg}$ ), a realistic pressure (say $100 \mathrm{psi}$ ), and a minimum number of revolutions, with degradation effects no greater than those found in the field.

74. Of the test methods investigated in this study, the highest densities were obtained with the MPVD method. The next highest densities were obtained with the MVT method, which produced densities that averaged 1 to 2 pcf less than those of the MPVD method. Since the reproducibility of results using either method is quite good,- their use for field control testing is justified.*

* Since this survey, the vibratory table method (or when its use is not feasible, the modified Providence vibrated density method) has been specified for determining the maximum density of cohesionless materials (see Headquarters, Department of the Army, op cit., $p$ 6). 
Table 1

Data on Compaction Apparatus and Procedures, WES Tests

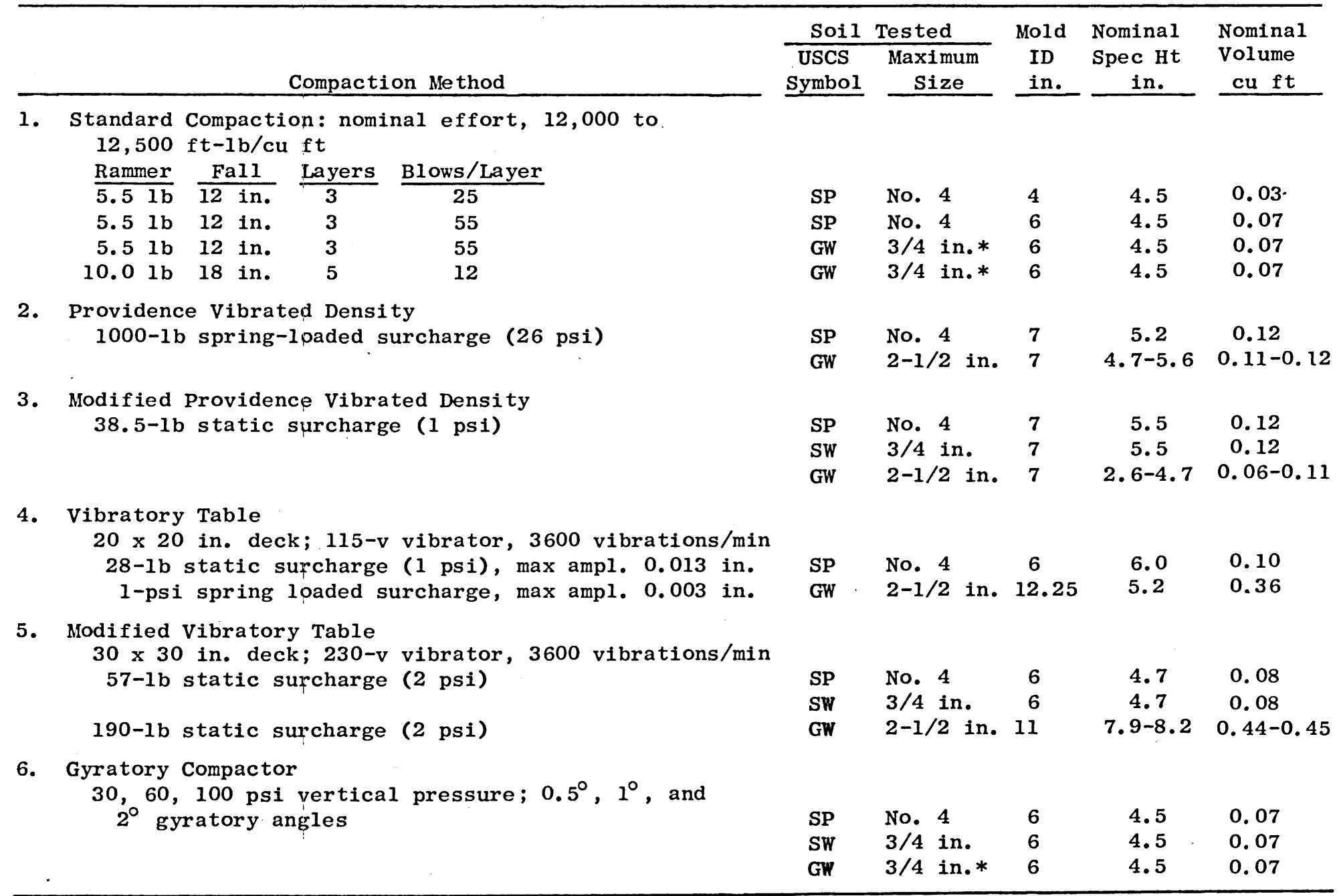

* plus 3/4-in. material replaced by equal amount of $3 / 4$ in. to No. 4 material 
Table 2

Summary of WES Compaction Tests (Excepting Gyratory), Hopkinton-Everett Sand (SP)

\begin{tabular}{|c|c|c|c|c|c|c|c|c|}
\hline \multirow[b]{2}{*}{ Type of Compaction Test } & \multicolumn{2}{|c|}{ Specimen } & Size & \multirow{2}{*}{$\begin{array}{c}\text { Dry } \\
w \\
\%\end{array}$} & Condition & \multirow{2}{*}{$\begin{array}{c}\text { Opt } \\
\text { w } \\
\% \\
\end{array}$} & \multirow{2}{*}{$\begin{array}{r}\operatorname{Max} \\
Y_{\mathrm{d}}\end{array}$} & \multirow[b]{2}{*}{ Operator } \\
\hline & $\begin{array}{l}\text { Diam } \\
\text { in. }\end{array}$ & $\begin{array}{l}\text { Ht } \\
\text { in. }\end{array}$ & $\begin{array}{l}\text { Vol } \\
\text { cu ft } \\
\end{array}$ & & $\begin{array}{r}Y_{\mathrm{d}} \\
\underline{1 \mathrm{~b} / \mathrm{cu} \mathrm{ft}} \\
\end{array}$ & & & \\
\hline \multirow{5}{*}{ Standard Effort Impact* } & 4.0 & 4.5 & 0.033 & 0.1 & 111.1 & 15.0 & 107.1 & TC \\
\hline & 4.0 & 4.5 & 0.033 & 0.1 & 109.8 & 15.1 & 107.5 & VP \\
\hline & 4.0 & 4.5 & 0.033 & 0.1 & 111.3 & 15.0 & 107.0 & ES \\
\hline & 4.0 & 4.5 & 0.033 & OD** & 111.7 & -- & -- & ES \\
\hline & 6.02 & 4.5 & 0.074 & 0.2 & 111.2 & 14.7 & 107.2 & ES \\
\hline \multirow{3}{*}{$\begin{array}{l}\text { Providence Vibrated Density, 1000-1b } \\
\text { Spring Load Surcharge }\end{array}$} & 7.0 & 5.24 & 0.117 & OD & 113.1 & -- & -- & ES \\
\hline & 7.0 & 5.21 & 0.116 & OD & 113.8 & -- & -- & TC \\
\hline & 7.0 & 5.27 & 0.117 & OD & 112.6 & -- & -- & VP \\
\hline \multirow{3}{*}{$\begin{array}{c}\text { Modified Providence Vibrated Density, } \\
\text { 1.0-psi (38.4 } 1 \text { b) Static Surcharge }\end{array}$} & 7.0 & 5.46 & 0.122 & OD & 117.8 & -- & -- & TC \\
\hline & 7.0 & 5.54 & 0.123 & OD & 116.2 & -- & -- & ES \\
\hline & 7.0 & 5.47 & 0.122 & OD & 117.6 & -- & -- & VP \\
\hline \multirow{3}{*}{$\begin{array}{l}\text { Vibratory Table, } 1.0-p s i \text { static } \\
\text { Surcharge (initial tests) }\end{array}$} & 6.0 & 5.96 & 0.097 & OD & 113.3 & -- & -- & ES \\
\hline & 6.0 & 6.04 & 0.098 & OD & 111.9 & -- & -- & $\mathrm{TC}$ \\
\hline & 6.0 & 5.99 & 0.098 & OD & 112.8 & -- & -- & VP \\
\hline \multirow{3}{*}{$\begin{array}{l}\text { Modified Vibratory. Table, 1.0-psi } \\
\text { Static Surcharge }\end{array}$} & 6.0 & 4.67 & 0.076 & OD & 115.5 & -- & -- & ES \\
\hline & 6.0 & 4.65 & 0.076 & OD & 115.7 & -- & -- & $\mathrm{AG}$ \\
\hline & 6.0 & 4.67 & 0.076 & OD & 115.4 & -- & -- & MJ \\
\hline
\end{tabular}

* Compacted in three layers with 5.5-1b rammer dropping 12 in., 25 and 55 blows per 1 ayer in $4-$ and 6-in. molds, respectively $(12,500$ and $12,260 \mathrm{ft}-1 \mathrm{~b} / \mathrm{cu} \mathrm{ft})$

** OD $=$ oven $\mathrm{dry}$ 
Table 3

Summary of WES Gyratory Compaction Tests, Hopkinton-Everett Sand (SP)

\begin{tabular}{|c|c|c|c|c|c|c|c|}
\hline \multirow[b]{2}{*}{$\begin{array}{c}\text { Test } \\
\text { No. }\end{array}$} & \multirow[b]{2}{*}{$\begin{array}{c}\text { Date of } \\
\text { Test } \\
\end{array}$} & \multirow[b]{2}{*}{ Operator } & \multicolumn{3}{|c|}{ Test Conditions } & \multirow[b]{2}{*}{$\begin{array}{r}\text { Number of }(2) \\
\text { Revolutions } \\
\end{array}$} & \multirow[b]{2}{*}{$\begin{array}{l}\text { Dry } \\
\text { Density } \\
\text { lb/cu ft } \\
\end{array}$} \\
\hline & & & $\begin{array}{l}\text { Vertical } \\
\text { Pressure } \\
\text { psi } \\
\end{array}$ & $\begin{array}{l}\text { Angle of } \\
\text { Gyration } \\
\text { deg } \\
\end{array}$ & $\begin{array}{c}\text { Water Content } \\
\text { After Test } \\
\% \\
\end{array}$ & & \\
\hline 1 & $6-4-62$ & ES & 60 & $1 / 2$ & $<0.1$ & 70 & 108.2 \\
\hline 2 & $5-14-65$ & AG & 60 & $1 / 2$ & $<0.1$ & 70 & 109.2 \\
\hline 3 & $5-14-65$ & $\mathrm{TC}$ & 60 & $1 / 2$ & $<0.1$ & 70 & 109.1 \\
\hline 4 & $4-10-62$ & ES & 30 & 1 & $<0.1$ & 90 & 107.9 \\
\hline 5 & $4-12-62$ & ES & 30 & 1 & 7.2 & 140 & 103.6 \\
\hline 6 & $4-11-62$ & ES & 30 & 1 & $13.3^{(1)}$ & 130 & 108.1 \\
\hline 7 & $4-12-62$ & ES & 60 & 1 & $<0.1$ & 110 & 111.5 \\
\hline 8 & $4-12-62$ & ES & 60 & 1 & 7.2 & 120 & 110.0 \\
\hline 9 & $4-12-62$ & ES & 60 & 1 & $12.6^{(1)}$ & 120 & 110.2 \\
\hline 10 & $6-7-62$ & ES & 60 & 1 & $<0.1$ & 100 & 110.5 \\
\hline 11 & $6-7-62$ & ES & 60 & 1 & 0.1 & 100 & 110.0 \\
\hline 12 & $6-7-62$ & ES & 60 & 1 & $<0.1$ & 120 & 109.7 \\
\hline 13 & $6-4-62$ & JB & 60 & 1 & $<0.1$ & 100 & 110.3 \\
\hline 14 & $6-4-62$ & $\mathrm{DE}$ & 60 & 1 & $<0.1$ & 100 & 109.9 \\
\hline 15 & $4-12-62$ & ES & 100 & 1 & 0.1 & 110 & 109.9 \\
\hline 16 & $5-14-65$ & $\mathrm{TC}$ & 100 & 1 & $<0.1$ & 100 & 113.1 \\
\hline 17 & $5-14-65$ & $A G$ & 100 & 1 & $<0.1$ & 100 & 113.0 \\
\hline 18 & $4-12-62$ & ES & 100 & 1 & 7.1 & 90 & 110.3 \\
\hline 19 & $4-12-62$ & $\mathrm{ES}$ & 100 & 1 & $13.0(1)$ & 110 & 109.6 \\
\hline 20 & $6-4-62$ & ES & 60 & 2 & $<0.1$ & 170 & 114.4 \\
\hline 21 & $5-14-65$ & $A G$ & 60 & 2 & $<0.1$ & 150 & 115.6 \\
\hline 22 & $5-14-65$ & $\mathrm{MJ}$ & 60 & 2 & $<0.1$ & 150 & 115.0 \\
\hline
\end{tabular}

NOTES:. (1) Free water lost during compaction

(2) Number of revolutions at which density was selected for comparison

(3) Density at which next 100 revolutions produced only 1 lb per cu ft increase 
Table 4

Summary of WES Compaction Test Densities, Hopkinton-Everett Sand (SP)

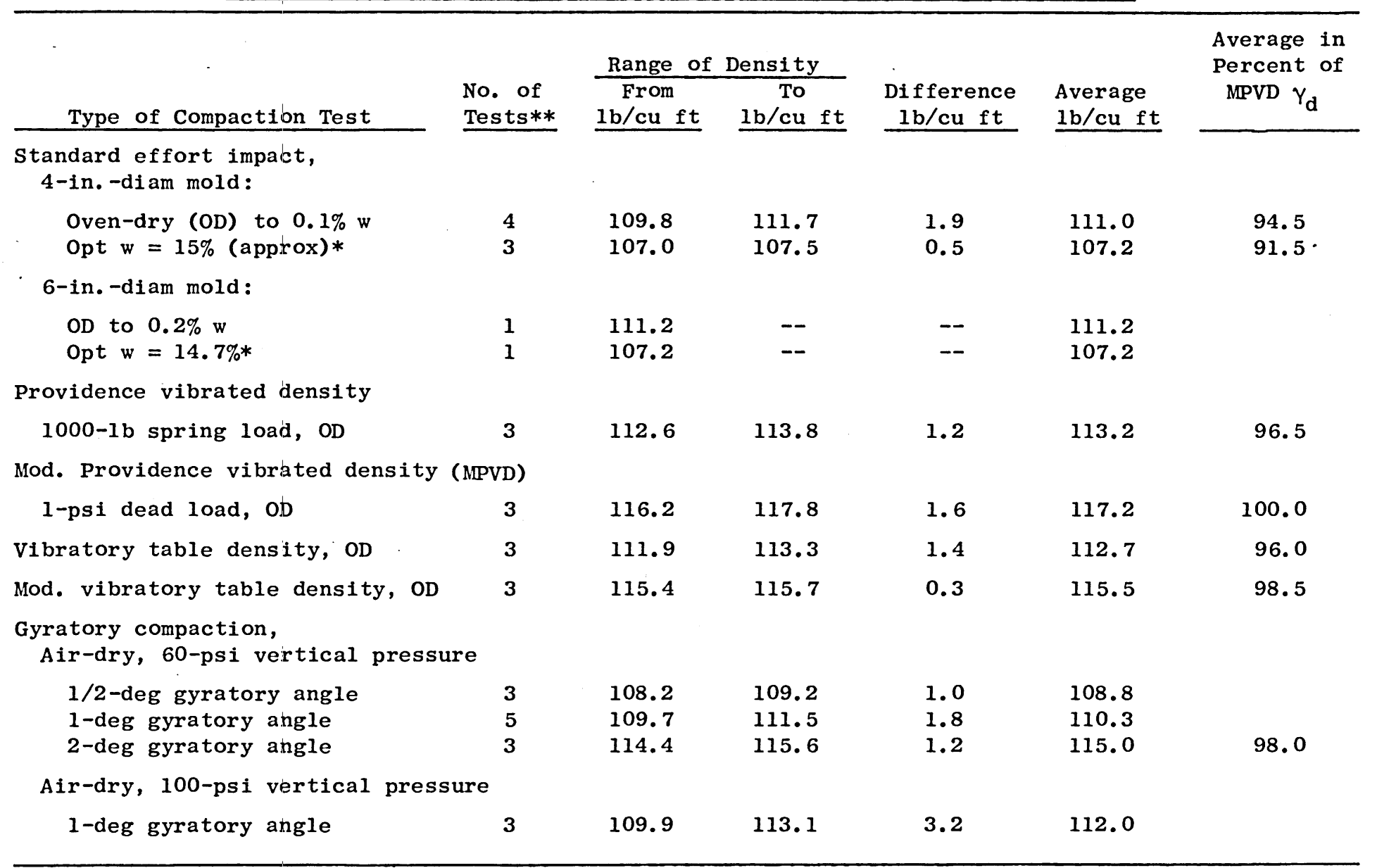

* Opt $w$ is that molding water content which results in the maximum density for standard effort (approximately $12,400 \mathrm{ft} 1 \mathrm{~b} / \mathrm{cu} \mathrm{ft}$ ), excluding consideration of the oven-dry condition.

** Three different technicians performed each type of test, except that only one impact compaction test at each of 2 water contents was performed using the 6 in. mold. 
Table 5

Summary of WES Compaction Tests on West Thompson Sand (SW)

\begin{tabular}{|c|c|c|c|c|c|c|c|}
\hline Type of Compaction Test & $\begin{array}{l}\text { Spe } \\
\text { Diam } \\
\text { in. }\end{array}$ & $\begin{array}{c}\text { cimen } \\
\mathrm{Ht} \\
\text { in. } \\
\end{array}$ & $\begin{array}{l}\frac{\text { Size }}{\text { Vol }} \\
\text { cu ft }\end{array}$ & $\begin{array}{l}\text { Number of } \\
\text { Revolutions }\end{array}$ & \multicolumn{2}{|c|}{ Dry Density ${ }^{(2)}$} & Operator \\
\hline $\begin{array}{l}\text { Modified Providence Vibrated Density, } \\
\text { 1-psi Static Load }\end{array}$ & $\begin{array}{l}7.0 \\
7.0 \\
7.0\end{array}$ & $\begin{array}{l}4.92 \\
5.04 \\
5.06\end{array}$ & $\begin{array}{l}0.110 \\
0.112 \\
0.113\end{array}$ & $\begin{array}{l}-- \\
-- \\
--\end{array}$ & $\begin{array}{r}120.7 \\
118.0 \\
117.3 \\
\text { Avg }\end{array}$ & 118.7 & $\begin{array}{l}\text { ES } \\
\text { MV } \\
\text { AG }\end{array}$ \\
\hline $\begin{array}{l}\text { Modified Vibratory Table Density, 1-psi } \\
\text { Static Load, 8-min Vibration Time }\end{array}$ & $\begin{array}{l}6.0 \\
6.0 \\
6.0\end{array}$ & $\begin{array}{l}5.11 \\
5.11 \\
5.11\end{array}$ & $\begin{array}{l}0.084 \\
0.084 \\
0.084\end{array}$ & $\begin{array}{l}-- \\
-- \\
--\end{array}$ & $\begin{array}{r}118.6 \\
118.0 \\
118.0 \\
\text { Avg }\end{array}$ & 118.2 & $\begin{array}{l}\text { ES } \\
\text { MJ } \\
\text { AG }\end{array}$ \\
\hline $\begin{array}{l}\text { Gyratory Compaction, 60-psi Vertical } \\
\text { Pressure: }\end{array}$ & & & & & & & \\
\hline 1/2-deg gyratory angle & $\begin{array}{l}6.0 \\
6.0 \\
6.0\end{array}$ & $\begin{array}{l}4.76 \\
4.73 \\
4.74\end{array}$ & $\begin{array}{l}0.062 \\
0.061 \\
0.061\end{array}$ & $\begin{array}{l}70 \\
60 \\
70\end{array}$ & $\begin{array}{r}113.1 \\
113.6 \\
114.0 \\
\text { Avg }\end{array}$ & 113.6 & $\begin{array}{l}\text { WR } \\
\text { ES } \\
\text { MJ }\end{array}$ \\
\hline 1-deg gyratory angle & $\begin{array}{l}6.0 \\
6.0 \\
6.0\end{array}$ & $\begin{array}{l}4.72 \\
4.72 \\
4.65\end{array}$ & $\begin{array}{l}0.061 \\
0.061 \\
0.062\end{array}$ & $\begin{array}{l}70 \\
90 \\
90\end{array}$ & $\begin{array}{r}114.1 \\
114.4 \\
115.9 \\
\text { Avg }\end{array}$ & 114.8 & $\begin{array}{l}\text { MJ } \\
\text { AG } \\
\text { ES }\end{array}$ \\
\hline 2-deg gyratory angle & $\begin{array}{l}6.0 \\
6.0 \\
6.0\end{array}$ & $\begin{array}{l}4.58 \\
4.52 \\
4.51\end{array}$ & $\begin{array}{l}0.057 \\
0.056 \\
0.055\end{array}$ & $\begin{array}{l}100 \\
150 \\
150\end{array}$ & $\begin{array}{r}117.7 \\
119.4 \\
119.6 \\
\text { Avg }\end{array}$ & 118.9 & $\begin{array}{l}\text { MJ } \\
\text { AG } \\
\text { ES }\end{array}$ \\
\hline
\end{tabular}

NOTE: (1) Number of revolutions at which density was selected.

(2) All tests performed on oven-day material. In gyratory compaction tests, these are the densities at which the next 100 revolutions produced less than 1 lb per cu ft. 
Table 6

Summary of WES Compaction Test Densities, West Thompson Sand (SW)

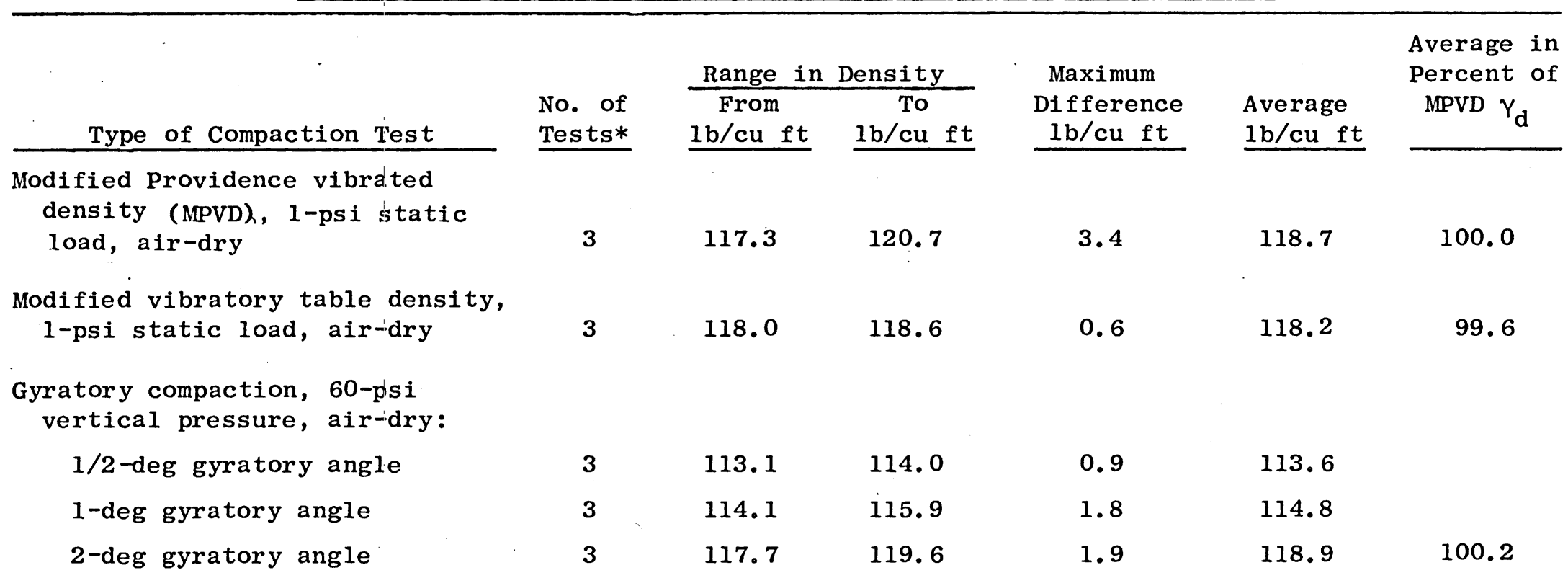

* Three different operators on each type of test 
Table 7

Summary of WES Tests (Excepting Gyratory), Painted Rock Sandy Grave1 (GW)

\begin{tabular}{|c|c|c|c|c|c|c|c|c|c|c|}
\hline \multirow[b]{2}{*}{ Type of Compaction Test } & \multicolumn{3}{|c|}{ Specimen Size } & \multicolumn{2}{|c|}{ Vibration } & \multicolumn{2}{|c|}{ Dry Condition } & \multirow{2}{*}{$\begin{array}{c}\text { Opt } \\
\mathrm{w} \\
\% \\
\end{array}$} & \multirow{2}{*}{$\begin{array}{c}\operatorname{Max} \\
Y_{d} \\
1 \mathrm{~b} / \mathrm{cu} \quad \mathrm{ft} \\
\end{array}$} & \multirow[b]{2}{*}{ Operator } \\
\hline & $\begin{array}{l}\text { Diam } \\
\text { in. }\end{array}$ & $\begin{array}{l}\mathrm{Ht} \\
\text { in. }\end{array}$ & $\begin{array}{l}\text { Vol } \\
\text { cu ft }\end{array}$ & $\begin{array}{r}\text { Time } \\
\text { min }\end{array}$ & $\begin{array}{l}\text { Ampl } \\
\text { in. }\end{array}$ & $\begin{array}{c}\mathrm{w}^{(1)} \\
\%\end{array}$ & $\begin{array}{c}Y_{d} \\
1 b / c u f t\end{array}$ & & & \\
\hline $\begin{array}{l}\text { Standard Effort Impact: } \\
\qquad 10-1 \text { b rammer }(2) \\
18-i n . \text { drop }\end{array}$ & $\begin{array}{l}6.06 \\
6.06 \\
6.06 \\
5.99\end{array}$ & $\begin{array}{l}4.50 \\
4.50 \\
4.50 \\
4.50\end{array}$ & $\begin{array}{l}0.075 \\
0.075 \\
0.075 \\
0.073\end{array}$ & $\begin{array}{l}-- \\
-- \\
-- \\
--\end{array}$ & $\begin{array}{l}-- \\
-- \\
-- \\
--\end{array}$ & $\begin{array}{l}-- \\
-- \\
-- \\
\text { OD }\end{array}$ & $\begin{array}{c}-- \\
-- \\
-- \\
126.9\end{array}$ & $\begin{array}{l}8.0 \\
8.0 \\
8.0 \\
--\end{array}$ & $\begin{array}{c}135.3 \\
136.4 \\
136.4 \\
--\end{array}$ & $\begin{array}{l}\text { TC } \\
\text { TC } \\
\text { TC } \\
\text { ES }\end{array}$ \\
\hline $5.5-1$ b rammer ${ }^{(3)} 12-i n$. drop & $\begin{array}{l}6.02 \\
6.02 \\
6.02\end{array}$ & $\begin{array}{l}4.50 \\
4.50 \\
4.50\end{array}$ & $\begin{array}{l}0.074 \\
0.074 \\
0.074\end{array}$ & $\begin{array}{l}-- \\
-- \\
--\end{array}$ & $\begin{array}{l}-- \\
-- \\
--\end{array}$ & $\begin{array}{l}-- \\
-- \\
--\end{array}$ & $\begin{array}{l}-- \\
-- \\
--\end{array}$ & $\begin{array}{l}6.3 \\
6.4 \\
6.4\end{array}$ & $\begin{array}{l}131.8 \\
131.4 \\
132.2\end{array}$ & $\begin{array}{l}\text { TC } \\
\text { ES } \\
\text { VP }\end{array}$ \\
\hline $\begin{array}{l}\text { Providence Vibrated Density, } \\
\text { 1000-1b Spring Load } \\
\text { Surcharge }\end{array}$ & $\begin{array}{l}7.0 \\
7.0 \\
7.0 \\
7.0 \\
7.0\end{array}$ & $\begin{array}{l}4.93 \\
4.80 \\
4.72 \\
5.61 \\
5.24\end{array}$ & $\begin{array}{l}0.110 \\
0.107 \\
0.105 \\
0.123 \\
0.117\end{array}$ & $\begin{array}{l}-- \\
-- \\
-- \\
-- \\
--\end{array}$ & $\begin{array}{l}-- \\
-- \\
-- \\
-- \\
--\end{array}$ & $\begin{array}{l}O D \\
O D \\
O D \\
O D \\
O D\end{array}$ & $\begin{array}{l}129.9 \\
133.2 \\
135.3 \\
138.0 \\
132.3\end{array}$ & $\begin{array}{l}-- \\
-- \\
-- \\
-- \\
--\end{array}$ & $\begin{array}{l}-- \\
-- \\
-- \\
-- \\
--\end{array}$ & $\begin{array}{l}\text { TC } \\
\text { TC } \\
\text { TC } \\
\text { VP } \\
\text { ES }\end{array}$ \\
\hline $\begin{array}{l}\text { Modified Providence Vibrated } \\
\text { Density, 1.0-psi ( } 38,4 \text { lb) } \\
\text { Static Surcharge }\end{array}$ & $\begin{array}{l}7.0 \\
7.0 \\
7.0 \\
7.0\end{array}$ & $\begin{array}{l}2.62 \\
4.72 \\
4.63 \\
4.26\end{array}$ & $\begin{array}{l}0.057 \\
0.102 \\
0.101 \\
0.095\end{array}$ & $\begin{array}{l}-- \\
-- \\
-- \\
--\end{array}$ & $\begin{array}{l}-- \\
-- \\
-- \\
--\end{array}$ & $\begin{array}{l}O D \\
O D \\
O D \\
O D\end{array}$ & $\begin{array}{l}136.0 \\
136.2 \\
139.2 \\
140.0\end{array}$ & $\begin{array}{l}-- \\
-- \\
-- \\
--\end{array}$ & $\begin{array}{l}-- \\
-- \\
-- \\
--\end{array}$ & $\begin{array}{l}\text { JB } \\
\text { ES } \\
\text { FH } \\
\text { TC }\end{array}$ \\
\hline $\begin{array}{l}\text { Vibratory Table, 1.0-psi } \\
\text { Surcharge }\end{array}$ & $\begin{array}{l}12.25 \\
12.25 \\
12.25\end{array}$ & $\begin{array}{l}5.25 \\
5.28 \\
5.15\end{array}$ & $\begin{array}{l}0.358 \\
0.360 \\
0.351\end{array}$ & $\begin{array}{l}13 \\
13 \\
15\end{array}$ & $\begin{array}{l}0.003 \\
0.003 \\
0.003\end{array}$ & $\begin{array}{l}\text { OD } \\
\text { OD } \\
\text { OD }\end{array}$ & $\begin{array}{l}136.9 \\
139.0 \\
139.7\end{array}$ & $\begin{array}{l}-- \\
-- \\
--\end{array}$ & $\begin{array}{ll}-- \\
--\end{array}$ & $\begin{array}{l}\text { ES } \\
\text { ES } \\
\text { ES }\end{array}$ \\
\hline $\begin{array}{l}\text { Modified Vibratory Table, } \\
\text { 1.0-psi Static Surcharge }\end{array}$ & $\begin{array}{l}11.0 \\
11.0 \\
11.0\end{array}$ & $\begin{array}{l}8.08 \\
7.94 \\
8.22\end{array}$ & $\begin{array}{l}0.444 \\
0.436 \\
0.452\end{array}$ & $\begin{array}{l}8 \\
8 \\
8\end{array}$ & $\begin{array}{l}0.02 \\
0.02 \\
0.02\end{array}$ & $\begin{array}{l}\mathrm{AD} \\
\mathrm{AD} \\
\mathrm{AD}\end{array}$ & $\begin{array}{l}133.1 \\
136.1 \\
131.9\end{array}$ & $\begin{array}{l}-- \\
-- \\
--\end{array}$ & $\begin{array}{l}-- \\
-- \\
--\end{array}$ & $\begin{array}{l}\text { ES } \\
\text { AG } \\
\text { TC }\end{array}$ \\
\hline
\end{tabular}

NOTES: (1) $O D=$ oven dry; $A D=\operatorname{air}$ dry

(2) Tests with 10-1b rammer: Material compacted in five layers with 12 blows per layer (12,000 to $12,320 \mathrm{ft}-1 \mathrm{~b} / \mathrm{cu} \mathrm{ft}$ )

(3) Tests with 5.5-1b rammer: Material compacted in three layers with 55 blows per layer $(12,260 \mathrm{ft}-1 \mathrm{~b} / \mathrm{cu} \mathrm{ft})$ 
Table 8

Summary of WES Gyratory

Compaction Tests, Painted Rock Sandy Gravel (GW) (1)

\begin{tabular}{|c|c|c|c|c|c|c|}
\hline $\begin{array}{l}\text { Test } \\
\text { No. } \\
\end{array}$ & $\begin{array}{l}\text { Oper- } \\
\text { ator } \\
\end{array}$ & $\begin{array}{c}\text { Vertical } \\
\text { Pressure } \\
\text { psi } \\
\end{array}$ & $\begin{array}{l}\text { Angle of } \\
\text { Gyration } \\
\text { deg } \\
\end{array}$ & $\begin{array}{c}\text { Water Content } \\
\text { After Test } \\
\% \\
\end{array}$ & $\begin{array}{r}\text { Number of } \\
\text { Revolutions }\end{array}$ & $\begin{array}{l}\text { Dry } \\
\text { Density } \\
\text { lb/cu ft } \\
\end{array}$ \\
\hline 1 & ES & 60 & $1 / 2$ & $O D$ & 110 & 127.7 \\
\hline 2 & $\mathrm{TC}$ & 60 & $1 / 2$ & OD & 110 & 127.3 \\
\hline 3 & WR & 60 & $1 / 2$ & $O D$ & 110 & 127.6 \\
\hline 4 & ES & 100 & $1 / 2$ & $6.70^{(4)}$ & 110 & 128.5 \\
\hline 5 & ES & 30 & 1 & $<0.1$ & 120 & 124.0 \\
\hline 6 & ES & 30 & 1 & 4.3 & 300 & 128.8 \\
\hline 7 & ES & 30 & 1 & $7.0^{(4)}$ & 400 & 134.3 \\
\hline 8 & ES & 60 & 1 & $<0.1$ & 120 & 125.4 \\
\hline 9 & ES & 60 & 1 & 4.4 & 120 & 128.4 \\
\hline 10 & ES & 60 & 1 & $6.9^{(4)}$ & 250 & 134.3 \\
\hline 11 & ES & 100 & 1 & $<0.1$ & 110 & 128.0 \\
\hline 12 & ES & 100 & 1 & 4.3 & 190 & 132.6 \\
\hline 13 & ES & 100 & 1 & $6.4^{(4)}$. & 260 & 135.9 \\
\hline 14 & JB & 100 & 1 & $6.8^{(4)}$ & 200 & 136.5 \\
\hline 15 & $\mathrm{DE}$ & 100 & 1 & $6.6^{(4)}$ & 300 & 136.5 \\
\hline 16 & WR & 60 & 2 & OD & 150 & 130.5 \\
\hline 17 & $\mathrm{AG}$ & 60 & 2 & OD & 150 & 131.3 \\
\hline 18 & $\mathrm{TC}$ & 60 & 2 & OD & 150 & 133.2 \\
\hline 19 & ES & 100 & 2 & 0.2 & 260 & 135.4 \\
\hline 20 & ES & 100 & 2 & 5.3 & 250 & 142.8 \\
\hline
\end{tabular}

NOTES: (1) Minus 3/4-in. material with replacement

(2) Number of revolutions at which density was selected for comparison

(3) Density at which next 100 revolutions produced only $1-1 b / c u$ ft increase

(4) Free water lost during compaction 
Table 9

Type of Test

A. Using -2-1/2-in. material:

Providence Vibrated Density, 1000-1b

(26.0-psi) Spring Load (oven dry)

Modified Providence Vibrated Density (MPVD),

1-psi Static Load (oven dry)

Vibratory Table Density (oven dry)

Modified Vibratory Table Density (air dry)

B. Using -3/4-in. material with replacement:

Standard Effort Impact,

10-1b rammer ( $8.0 \%$ opt w)

5.5-1b rammer (6.4\% opt w)

Gyratory Compaction, 60-psi Vertical Pressure,

$1 / 2$-deg gyratory angle (OD)

1 -deg gyratory angle (OD)

2-deg gyratory angle (OD)

1 -deg gyratory angle $(w=7 \%)$

Gyratory compaction, 100-psi Vertical pressure, 1-deg gyratory angle (OD)

2-deg gyratory angle (OD)

$1 / 2-$ deg gyratory angle $(w=6.7 \%)$

1 -deg gyratory angle $(w=6.6 \%+)$

$2-$ deg gyratory angle $(w=5.3 \%)$

\begin{tabular}{l} 
No. \\
of \\
Tests \\
\hline
\end{tabular}

Max
Diff.
b/cu ft

$5 \quad 129.9$ to 138.0

$8.1 \quad 133.7$

Average

$\underline{1 \mathrm{~b} / \mathrm{cu} \mathrm{ft}}$

Average

in Percent

of MPVD

$\gamma_{d}$

$4 \quad 136.0$ to 140.0

4.0

137.8

$3 \quad 136.9$ to 139.7

2.8

138.5

$3 \quad 131.9$ to 136.1

4.2

133.7

100.5

97.0

135.3 to 136.4

1.1

136.0

0.8

131.8

98.6 131.4 to 132.2

0.4

127.3 to 127.7

127.5

130.5 to 133.2

2.7

125.4

3

1

--

$-$

131.7

134.3

95.5

$-$

$-$

$--$

135.9 to 136.5

--

$--\quad 128.0$

-- 135.4

$--128.5$

$0.6 \quad 136.3$

98.2

99.0 
Table 10

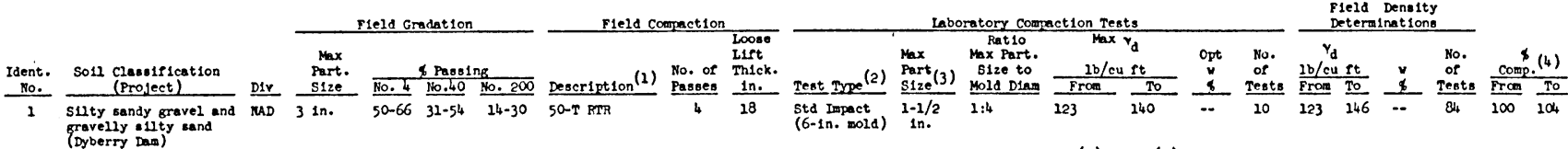

2 Silty sandy gravel and raD 3 1n. 50-65 31-54 14-30 50-T RTR Eravelly ollty sand

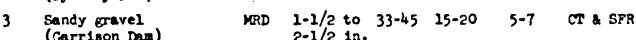
$\begin{array}{llllll}\text { Sandy gravel } & \text { NED } 3 \mathrm{ln} \text {. } 35-43 & 10-12 & 1-2 & 21-\mathrm{T} & \mathrm{CT}\end{array}$

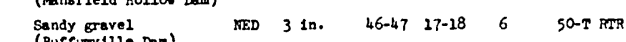

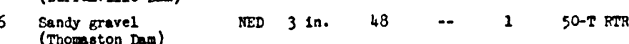

$7 \begin{aligned} & \text { Sandy gravel (Painted } \\ & \text { Rock Dam, Zone IV) }\end{aligned}$ SPD 3 in. + $35 \quad 14 \quad 3 \quad$ 50-T RTR

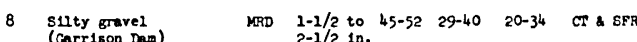

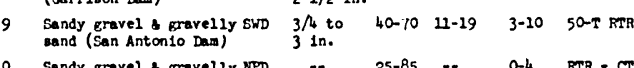
Sandy gravel \& gravelly NPD
sand (Lucky Peak Das, Test Ful)

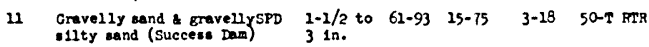

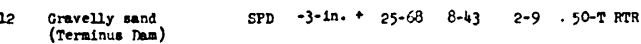

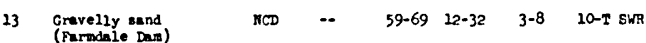

$14 \begin{aligned} & \text { Gravelyy eand } \\ & \text { (Barkiley Dam) }\end{aligned} \quad$ ORD $3 / 4$ in. $88 \quad 42 \quad 1 \quad$ RTR

$15 \begin{aligned} & \text { Grovelly sand } \\ & \text { (Union Village Dam) }\end{aligned}$ NED 1 in. 70-89 23-40 1-9 D-8 Cr

$16 \begin{aligned} & \text { Gravelly sand } \\ & \text { (Mangville Bollow Dam) }\end{aligned}$ NED 1 to 3 in. $54-83 \quad 21-59 \quad 1-3 \quad$ D-8 CT

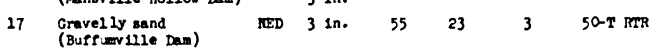

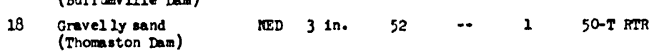

19 Silty gravelly sand a SPD $3 / 4$ to $63-96 \quad 26-65 \quad 11-42 \quad 50-\mathrm{T}$ RTR
31 1n. (San Antonio Dam)

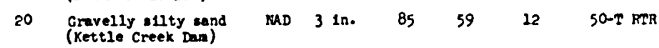

21 Gravelly silty sand \& SPD 3/4 to 63-96 26-65 21-42 50-9 RTR (11ty sand (Santonio Dam)

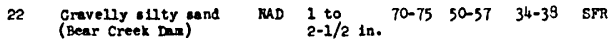

23 Sand, Pline (Port Allen Lock) IND No. $40 \quad 100 \quad 100 \quad 0$ Flooded - CT

$4 \quad 18$ Std Impact \$o. 4 $\begin{array}{llllllllll}136(5) & 146^{(5)} & \ldots & 11 & 133 & 146 & 6-11 & 11 & 92 * & 102 *\end{array}$

24 Sand, medium P1ne SWD no. $10 \quad 100 \quad 74-84 \quad 5-6 \quad \begin{aligned} & \text { Hauling } \\ & \text { (Keystone Dam) }\end{aligned}$

25 Sand (West Thompson NED 1-1/2 1n. $77-87 \quad 19-33$ 1.5 50-T RTR

26 Sand, medsum (1 Fla. SAD No. 4 -.

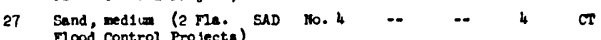

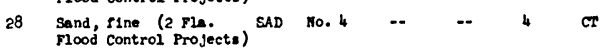

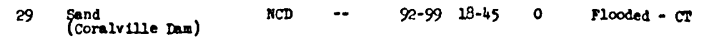

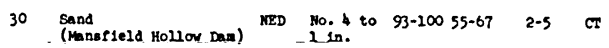

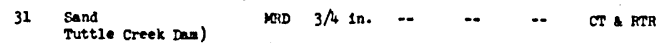

Sand (Hopkington- MED No. 4 to $76-100$ 14-94 $2-24$
Everette Project D1ke P-1) $1-1 / 2$ in.

SO-T RTR
(Seturated)

33 S1lty and (Lucky, RPD No. 4 85-92

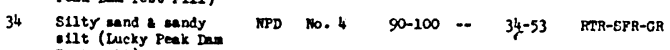

35 Silty and (Eufaule Dam)SWD 2 in. $\quad$-- $\quad 75-97 \quad 20-47 \quad$ SFR 4 50-T RTR

$36 \begin{aligned} & \text { Silty sand } \\ & \text { (Keystone Das) }\end{aligned} \quad$ STD No. $4 \quad 100 \quad 88 \quad 26 \quad \begin{aligned} & \text { Heuling } \\ & \text { equipment }\end{aligned}$

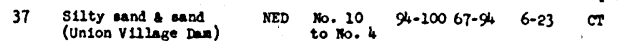

Mod. Impact
$(4-1$. nold $)$

PVD $\quad 2-1 / 2 \quad 1: 2.8 \quad 136$

PVD

PVD

$2-1 / 2 \quad 1: 2.8 \quad 141$

$2-1 / 2 \quad 1: 2.8 \quad 128$

Mech. vibre: $3 \mathrm{in}$.

tion -1 -po

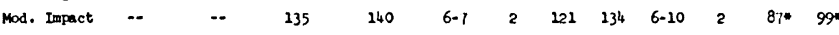

24 Std Inpact $3 / 4$ in. $1: 5.3 \quad 125 \quad 130$

$2-418$ Sta Impact No. $4 \quad$ Averapes+119 $12 \quad \ldots \quad 21 / \quad 21 \quad 2380 \quad 98$

$2-418$ Sta Impact No. $4 \quad$ Averapes+119 $12 \quad \ldots \quad 21 / \quad 21 \quad 2380 \quad 98$

$\begin{array}{llllllll}- & - & 114 & 139 & -. & 14 & 91 & 107\end{array}$

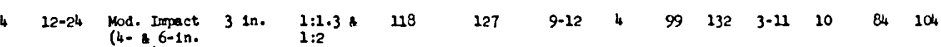

18-1n.-diam 3 in. $\quad 1: 6 \quad 133$ $3-1$ ayer test
/ $30-10$ hamer

18-1n. drop
18 .

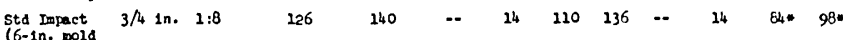
(6-1n. mold
v/replcut )

Std Impact $3 / 41 \mathrm{n} .1: 5.3 \quad$ Averages $\rightarrow 119$

WD 120

$\begin{array}{llllllllll}226 & 142 & \quad . & 4 & 116 & 134 & 4-10 & 4 & 90 * & 94 *\end{array}$

$2-1 / 2 \quad 1: 2.8$

128

$\begin{array}{lllllllll}143 & - & 4 & 123 & 143 & 3.14 & 4 & 95 * 100 *\end{array}$

PVD

$\begin{array}{ccc}2-1 / 2 \\ 1 \text {. }\end{array} \quad 1: 2.8 \quad 242$

FD $\quad \begin{array}{lll}2-1 / 2 & 1: 2.8 \quad 115 \\ 1 \mathrm{nn} & & \end{array}$

$\begin{array}{llllllllllllllllllllll}- & -. & 1 & 142 & - & 6 & & 1 & 100 & \cdots\end{array}$

Std Impact $3 / 4$ in. $1: 5.3 \quad 124$

$\begin{array}{llllllllllllllll}* & 1 & 110 & - & 3 & 1 & 96 & \ldots\end{array}$

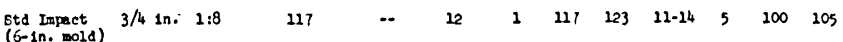

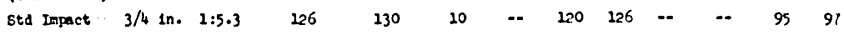

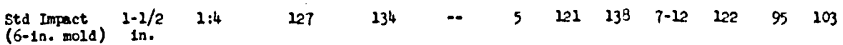

Std Impact No. 40

Std Inpect No. 10

PVD $\quad \begin{aligned} & 1-1 / 2 \\ & 1 \mathrm{n} .\end{aligned} \quad 1: 4.7$

$\begin{array}{lllllllllllllll}-. & 11 & 1 & 98 & 108 & \ldots & . . & 100 & 110\end{array}$

$\begin{array}{lllllllll}214 & 10-14 & 3 & 105 & 111 & -. & -. & 91 & 100\end{array}$

$129 \quad--\quad \begin{array}{lllllll}4 & 115 & 226 & 3-9 & 14 & 94 * & 98 *\end{array}$

Std Impact No. 4

Mod. Impect No. 4

Gtd Impact No. 4

4-1n.-mold; $3 / 4 \mathrm{ln} . \quad 1: 5.3$

vibrated,

roturated

otruck

$\begin{array}{lllllllllllll}\text { PVD } & 1 \mathrm{ln} . & 1: 7 & 117 & 120 & -. & 2 & 114 & 116 & 0-9 & 2 & 97 * & 96 *\end{array}$

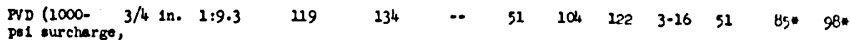
Pel surcharge,
atruck by$$
\text { hammer) }
$$

NOTES: (1) RTR - rubber-t Lred roller; SFR - sheepefoot roller; SWR - ateel. vhoel roller; $C T$ - cravler tractor; and GR - grid roller.

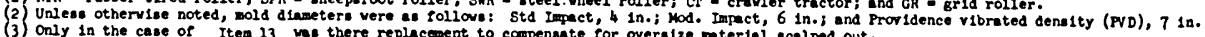

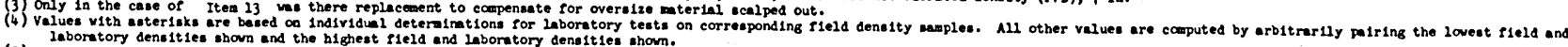
(5) computed fros laboratory tests for total fleld sample. 
Table 11

Field and Laboratory Compaction Data, Sand (SP) Hopkinton-Everett Project, Borrow Area D - Dike P1

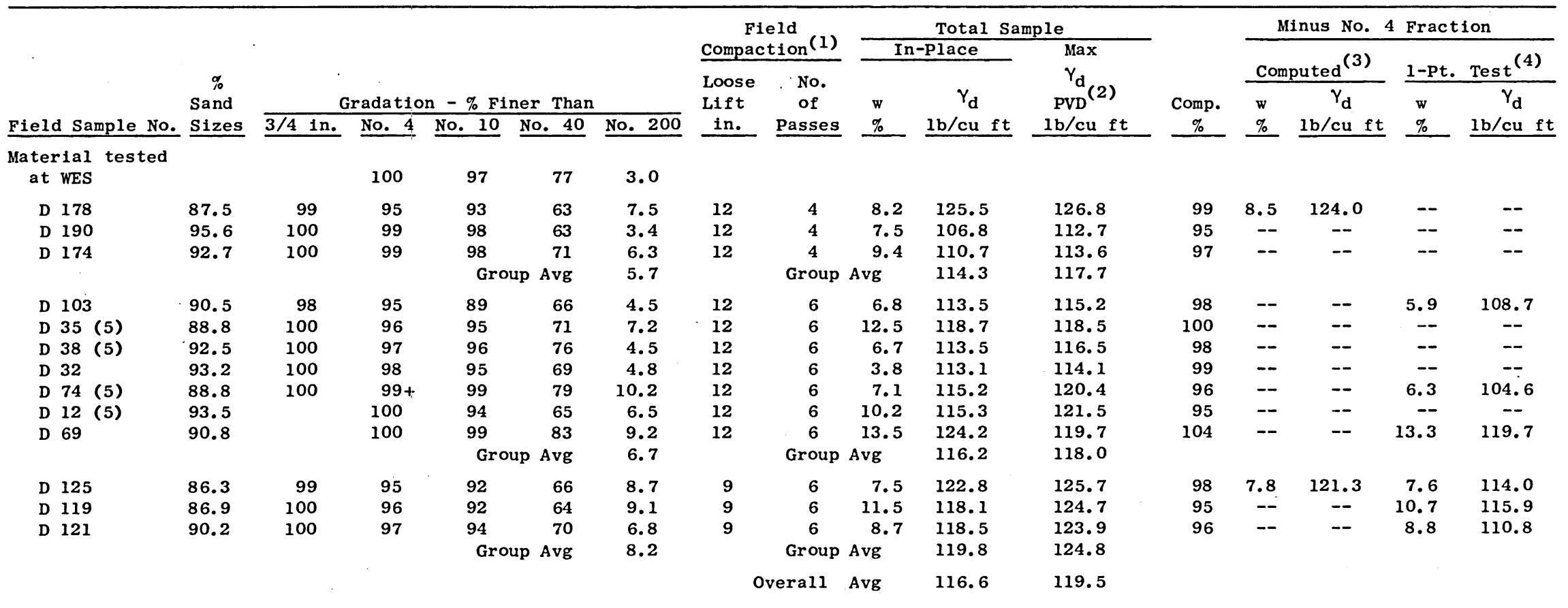

General Notes: a. Samples taken in period May-October 1960.

bata grouped in order of increasing field compaction effort, and in each group in order of increasing percent passing No. 4 sieve.

Column Notes: (1) 50-ton rubber tired roller

(2) Providence vibrated density test

(3) Computed from in-place data of total sample

(4) Standard impact compaction on minus No. 4 fraction of field sample at field w

(5) Gradation data on bag samples taken adjacent to density tests; all other gradation data on density samples 
Table 12

Field and Laboratory Compaction Data, Sand (SW) West Thompson Dam

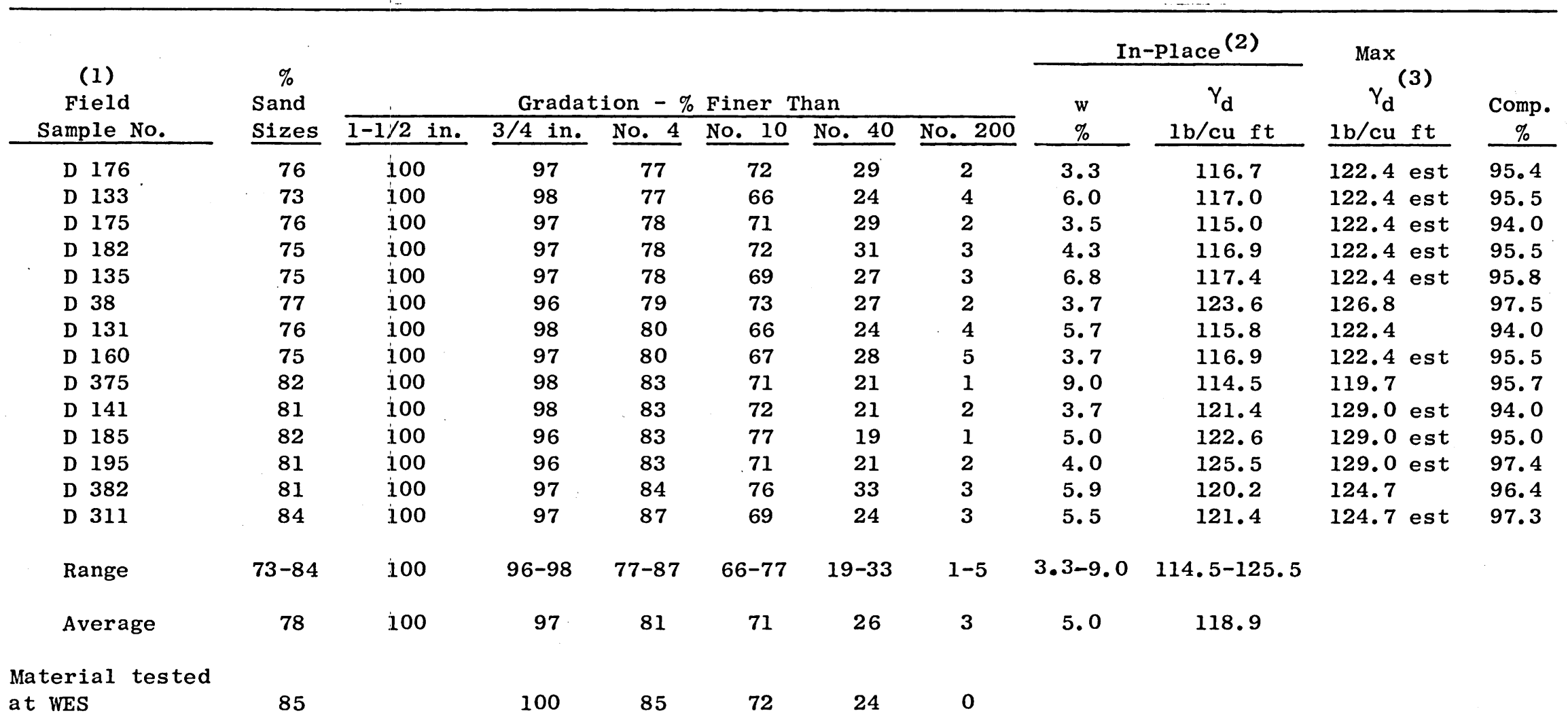

Notes: (1) Data grouped in order of increasing percent passing No. 4 sieve

(2) Field compaction using 50-ton pneumatic roller: three passes over 8-in. 1oose 1ift

(3) Providence vibrated density; est = estimated from previous test on same gradation 
Table 13

Field and Laboratory Compaction Data, Sandy Gravel (GW) Painted Rock Dam (Zone IV)

\begin{tabular}{|c|c|c|c|c|c|c|c|c|c|c|}
\hline & \multirow{3}{*}{$\begin{array}{r}\text { Soil } \\
\text { Class. }\end{array}$} & \multicolumn{5}{|c|}{ Gradation } & \multicolumn{2}{|c|}{ In-Place ${ }^{(1)}$} & \multicolumn{2}{|c|}{$\begin{array}{c}\text { Vibratory } \\
\text { Table }\end{array}$} \\
\hline & & $\begin{array}{c}\% \\
\text { Sand }\end{array}$ & \multicolumn{4}{|c|}{$\%$ Finer Than } & $w$ & $Y_{d}$ & $\mathrm{w}$ & $\gamma_{d}$ \\
\hline & & Sizes & No. 4 & No. 10 & No. 40 & No. 200 & $\%$ & $\underline{1 b / c u ~ f t}$ & $\%$ & $1 \mathrm{~b} / \mathrm{cu} \mathrm{ft}$ \\
\hline \multirow{4}{*}{$\begin{array}{l}\text { Design max. density } \\
\text { tests by SPD } \\
\text { laboratory }\end{array}$} & GP & 35 & 36 & & & 1 & & & sat. & 127 \\
\hline & GW & 30 & 32 & & & 2 & & & Sat. & 135 \\
\hline & GW & 34 & 36 & & & 2 & & & Sat. & 136 \\
\hline & & & & & & & & & Avg & 133 \\
\hline \multicolumn{11}{|l|}{$\begin{array}{l}\text { Large field density } \\
\text { test }(2.8 \mathrm{cu} \mathrm{ft})\end{array}$} \\
\hline made March 1959 & GW & & 35 & 27 & 14 & 3 & - & 142.5 & & \\
\hline $\begin{array}{l}\text { Field control tests } \\
\text { (std sand cone) }\end{array}$ & & & $\begin{array}{c}38 \\
(1735)\end{array}$ & & & $\begin{array}{c}3 \\
(1630)\end{array}$ & $\begin{array}{c}3 \\
(214)\end{array}$ & 135 & & \\
\hline \multicolumn{11}{|l|}{$\begin{array}{l}76 \text { sand cone density } \\
\text { tests reported by LAD } \\
\text { as typical of Zone IV } \\
\text { material sent to WES }\end{array}$} \\
\hline Range & & $27-34$ & $30-35$ & & & $1-5$ & $1-8$ & $121-153$ & & \\
\hline Average & & 30 & 33 & & & 2 & 3 & 139 & & \\
\hline Material tested at WES & GW & 34 & 34 & 28 & 15 & 1 & & & & \\
\hline
\end{tabular}

Notes: (1) Zone IV compacted in 24-in. lifts by 4 passes of a 50-ton rubber-tired roller

(2) Vibration under 1-psi surcharge load

(3) Figures in parentheses show number of samples tested 
Unclassified

Security Classification

DOCUMENT CONTROL DATA - R \& D

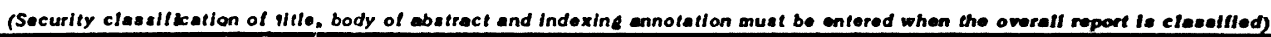
1. TRIGINATING ACTIVITY (Corporale euthor) 20. REPORT SECURITY CLASSIFICATION

U. S. Army Engineer Waterways Experiment Station $\quad$ Unclassified

Vicksburg, Mississippi

3. REPOAT TITLE

COMPACTION OF COHESIONLESS MATERIAIS

4. DESCRIPTIVE NOTES (TYPo of roporf and Inclualve datee)

Final report

8. AU THOR(s) (Firol name, middio initial, leot name)

Joseph R. Compton

William E. Strohm, Jr.

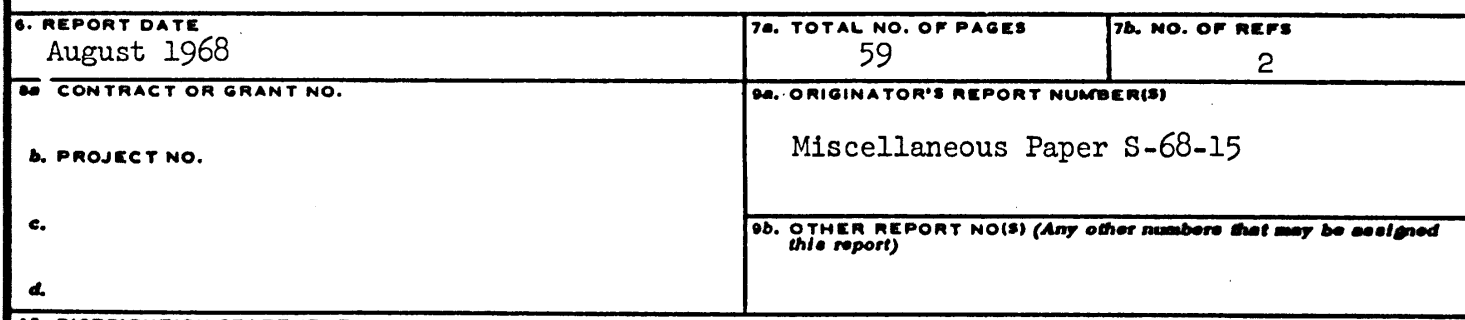

10. DISTAIDUTION STATEMEMIT

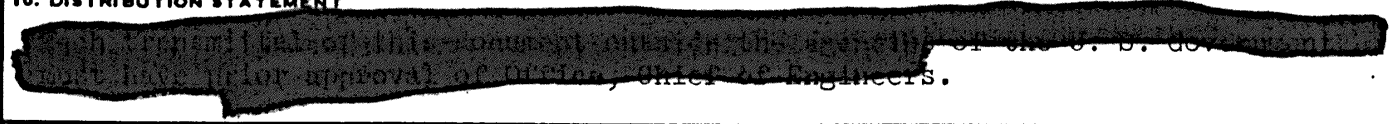

\begin{tabular}{l|l} 
11. SUPPLEMENTARY NOTES & 12. SPONSORING MILITARY ACTIVITY
\end{tabular}

Office, Chief of Engineers, U. S. Army Washington, D. C.

13. A0sthact This report contains data on laboratory and field compaction of cohesionless

soils obtained from a survey of Corps of Engineers division laboratories, and results of different types of laboratory compaction tests performed in the U. S. Army Engineer Waterways Experiment Station (WES) laboratory on three cohesionless materials. The tests at WES were conducted to study various laboratory compaction test methods used for cohesionless materials. The three materials tested were a poorly graded sand (SP), a well-graded sand (SW), and a sandy gravel (GW). Impact, Providence vibrated density, vibratory table, and gyratory compaction test methods were used. Replicate tests were conducted on each soil to determine the variations in maximum dry density resulting from different test methods. Different technicians conducted the replicate tests in order that the variations in test results due to different techniques could be determined. Selected tests were also conducted on dry and wet specimens to determine the effect of water content on resulting densities. Gyratory tests were conducted using different angles of gyration and different vertical pressures to determine the effects-of thesevariables. Based on the results of the compaction tests on the three materials used in the study it is concluded that the vibratory table test method gives the best results and the Providence vibrated density test method gives results comparatively close to those derived from the vibratory table test method. 
Unclassified

Security Classification

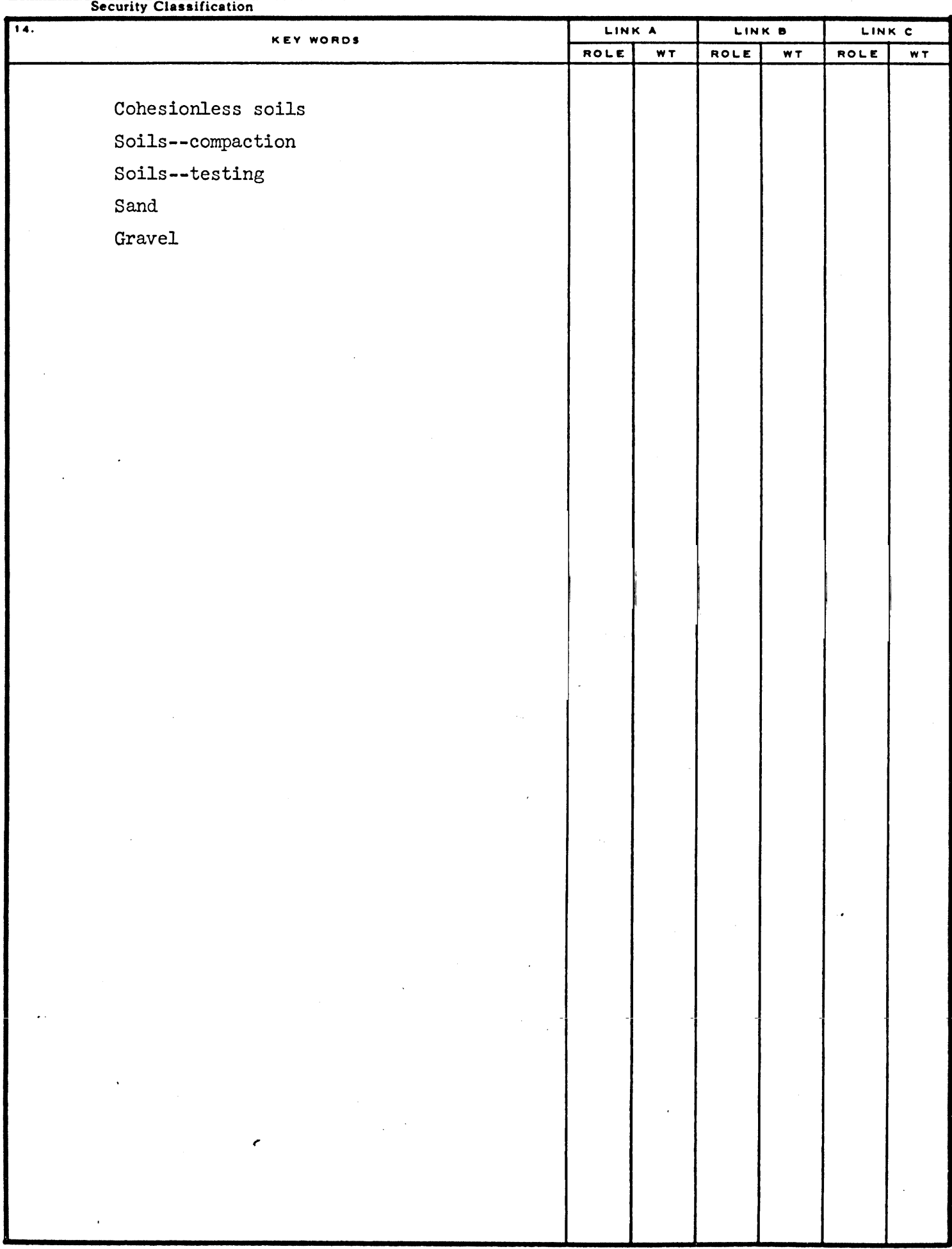

Unclassified 